\title{
A Moment in Human Development: Legal Protection, Ethical Standards and Social Policy on the Selective Non-Treatment of Handicapped Neonates
}

Lawrence O. Gostin

Georgetown University Law Center, gostin@law.georgetown.edu

This paper can be downloaded free of charge from:

https://scholarship.law.georgetown.edu/facpub/768

11 Am. J.L. \& Med. 31-78 (1985)

This open-access article is brought to you by the Georgetown Law Library. Posted with permission of the author. Follow this and additional works at: https://scholarship.law.georgetown.edu/facpub

Part of the Bioethics and Medical Ethics Commons, Health Law and Policy Commons, Health Policy Commons, and the Human Rights Law Commons 


\title{
A Moment in Human Development: Legal Protection, Ethical Standards and Social Policy on the Selective Non-Treatment of Handicapped Neonates
}

\author{
Larry Gostin*
}

\section{ABSTRACT}

Selective non-treatment decisions involving severely handicapped neonates have recently come under renewed judicial and legislative scrutiny. In this Article, the Author examines the legal, ethical and social considerations attendant to the non-treatment decision. In Part II of this Article the Author discusses the predominant ethical viewpoints relating to this issue and proposes a new moral standard based on personal interests. Part III presents a survey of the jurisprudence relating to selective non-treatment decisions. Parts IV and $V$ of this Article provide a critical examination of the recently enacted Child Abuse Amendments of 1984, a federal legislative initiative designed to regulate treatment decisions relating to handicapped infants. The Author suggests that the ethical standards and treatment criteria proposed in this Article may prove useful to courts seeking to balance the handicapped neonate's constitutional right to privacy with the requirements of the new federal law.

\section{INTRODUCTION}

A fetus in the womb, once viable, ${ }^{1}$ is considered in law to be deserving of protection. The viable fetus, even if there is certainty that it is handi-

* Senior Fellow in Health Law, Harvard University School of Public Health. B.A., summa cum laude, 1971, State University of New York at Brockport; J.D., 1974, Duke University. The author wrote this Article while a Visiting Fellow in Law and Medicine, Oxford University, Centre for Criminological Research. The author would like to acknowledge the assistance he received from William Curran, Frances Glessner Lee Professor of Legal Medicine, Harvard School of Medicine; Derek Russell Davis, Dean of the Faculty of Medicine and Emeritus Professor of Psychiatry, Bristol University; Professors Peter Mittler and Cliff Cunningham of the Hester Adrian Research Centre for the Study of Learning Processes in the Mentally Handicapped, University of Manchester; Professor Dr. Bernd Schulte, Max-PlanckInstitut, Munich; Gunnar Dybwad, Professor Emeritus of Human Development, Florence Heller School for Advanced Studies in Social Welfare, Brandeis University; and Professor Joan Bicknell, St. Thomas, Medical School, University of London.

1 A fetus in a human being refers to the products of conception from the beginning of the third month of pregnancy until birth. The term viability is medically applied to the human fetus from about the 28th week of gestation at which stage it may be capable of survival. Concise Oxford Medical Dictionary 235 (Corgi ed. 1982). 
capped, has a constitutional right to privacy and must be protected from harm. ${ }^{2}$

The young child is regarded as a person, and although its parents have great discretion, the child is protected by constitutional guarantees as well as state and federal child welfare legislation. Any parental decision affecting the child's welfare is measured against the well established legal principle of the child's best interests, i.e., the interests the child would follow if he or she were competent. Thus, even if a child suffers from a severe handicap-whether it existed at birth or arose later as a result of accident or disease-the parents have a responsibility to protect it from serious harm where recognized effective medical interventions are available. ${ }^{3}$

There has emerged, however, a jurisprudential and ethical view which appears to demarcate a highly vulnerable moment in human development where traditional child protection principles are seriously diminished. During this short period, days or weeks following birth, it is argued, a parent should have the right to allow the withholding of feasible life-saving medical procedures from the severely handicapped neonate.

The practice of keeping treatment decisions affecting infants within the domain of the parents and attending physician is, in fact, not new and it has gained strong support in the legal and medical literature. ${ }^{4}$ That prac-

${ }^{2}$ The constitutional underpinning of Roe v. Wade, 410 U.S. 113 (1973), was that the right to privacy includes freedom of personal choice in certain matters of marriage and family. See also Harris v. McRae, 448 U.S. 297 (1980). Familial or parental choice in effectuating the constitutional right to privacy is, however, only one interest to be balanced among others; from the moment of viability, the principal interest is that of the infant. It is the thesis of this essay that this balancing of interests is not fundamentally altered by either the fact of the birth of a severely handicapped infant or the long-term worth of the life to be protected. Although the Supreme Court in Roe v. Wade, 410 U.S. at 156-58, held that a fetus was not a person under the Fourteenth Amendment, it indicated that a newborn, and by implication a handicapped newborn, is a person deserving of constitutional protection. See Commonwealth v. Edelin, 371 Mass. 497, 359 N.E.2d 4 (1976) (conviction of a physician for manslaughter of an aborted but arguably "live" fetus reversed because only a fetus "born alive outside its mother" can be a "person"). For a discussion of the Edelin case see P. Ramsey, Ethics at the Edge of Life: Medical and Legal. Intersections 94-141 (1978).

${ }^{3}$ See infra notes $49-53$ and accompanying text.

${ }^{4}$ See British Medical Association, The Handbook of Medical Ethics 29 (1980) (amended by the BMA in 1983, 286 British Medical Journal 593, (1983); H. Kuhse \& P. Singer, Should the Baby Live? The Problem of Handicapped Infants (1985); Davis, Ethical Issues in Neonatal Care, in Parent and Infant Atrachment in Premature Babies (J. Davis, M. Richard \& C. Robertson, eds. 1984); Englehardt, Ethical Issues in Aiding the Death of Young Children, in Killing and LeTting Die (B. Steinbeck, ed. 1980); T. Baldwin, Life and Death in Newborn Special Care Units (March 1982) (available at Connecticut State Dept. of Health Services); Campbell \& Duff, Deciding the Care of Severely Malformed or Dying Infants, 5 J. MED. Errics 65 (1979); Duff \& Campbell, Moral and Ethical Dilemmas in the Special-Care Nursery, 289 New ENG. J. MED. 890 (1973); Englehardt, Euthanasia and Children; The Injury of Continued Existence, 83 J. Pediatrics, 170 (1973); Fletcher, Abortion, Euthanasia and Care of Defective Newborns, 292 New Eng. J. Medicine 75 (1975); Goldstein, Medical Care for the Child at Risk: On State Supervention of Parental Autonomy, 86 YALE L.J. 645, 651-61 (1977); Goldstein, Not for the Law to Approve or Disapprove-A Comment on Professor Mnookin's Paper, 1984 ARIz. STATE L.J. 
tice came under the full gaze of public scrutiny in the "Baby Doe" case, where the Indiana Supreme Court approved a parental decision to withhold treatment for a remediable tracheo-esophageal fistula ${ }^{6}$ in an infant born with Down's Syndrome.

The Baby Doe case has been used as the moral underpinning for the Child Abuse Amendments of 1984. This legislation and its accompanying regulations ${ }^{7}$ intimately control medical and parental decision-making at the

685; Harris, Ethical Problems in the Management of Some Severely Handicapped Children, 7 J. MED. ETHICs 117 (1981); Kuhse, A Modern Myth that Letting Die is Not the Intentional Causation of Death: Some Reflections on the Trial and Acquittal of Dr. Leonard Arthur, $1 \mathrm{~J}$. OF APPLIEd PHILosophy 21 (1984); Lorber, Ethical Problems in the Management of Myelomeningocele and Hydrocephalus, $10 \mathrm{~J}$. Roy'l College of Physicians of London 47 (1975); McCormick, To Save or Let Die-The Dilemma of Modern Medicine, 229 J.A.M.A. 172 (1974); Myer, Protecting the Best Interests of the Child: Is the State a Necessary Blunt Instrument, 1984 A rizona STATE L.J. 627; Smith, Quality of Life, Sanctity of Creation: Palliative or Apotheosis, 63 NEB. L. Rev. 709 (1984); Tooley, Abortion and Infanticide, 2 Philosophy \& Pur. Afr. 37 (1972); Williams, Down's Syndrome and the Duty to Preserve Life, 131 New L.J. 1020 (1981); Williams, Down's Syndrome and the Doctor's Responsibility, 133 New L.J. 1040 (1981); Comment, Baby Doe Decisions: Modern Society's Sins of Omission, 63 NeB. L. Rev. 888 (1984). Other commentators have argued for careful control over nontreatment decisions. See Burt, Authorizing Death for Anomolous Newborns, in GeNeTICS AND THE LAw 435 (A. Milunsky \& G. Annas, eds. 1976); Freund, Mongoloids and "Mercy Killing," in Ethics in Medicine: Historical Perspectives and Contemporary Concerns 536 (S.J. Raiser, A.J. Dyck \& J. Curran, eds. 1977); P. Ramsey, supra note 2, at 189-227; A. Shearer, Everyody's Ethics: What Future for Handicapped Babies? (1984); Annas, "A Wonderful Case and an Irrational Tragedy": The Phillip Becker Case Continues, 12 HAst. CEN. RPT. 25 (Feb. 1982); Brant \& McNulty, Treating Defective Newborns: The Ethical Dilemma, 10 Hum. RTs. 34 (1982); Bridge \& Bridge, The Brief Life and Death of Christopher Bridge, 11 HAST. CEN. RPT. 17 (Dec. 198 1); Coburn, Morality and the Defective Newbom, 5 J. Med. And Philosophy 340 (1980); Ellis, Letting Defective Babies Die: Who Decides? 7 AM. J.L. \& MEd. 393 (1982); Fost, Baby Doe: Problems and Solutions, 1984 ARI\%. STATE L.J. 637; Gostin, Court of Appeal's Authorization of Operation on Infant with Down Syndrome, The LANCET 467 (August 29, 1981); Heymann \& Holtz, The Severely Defective Newborn: The Dilemma and Decision Process, 23 Puв. Policy 381 (1975); Johnson, Selective Non-Treatment and Spina Bifida: A Case Study in Ethical Theory and Application, 3 Bioethics Quakt. 91 (1981); Johnson, Selective Non-Treatment of Defective Newborns; An Ethical Analysis, 47 Linacre QuART. 39 (1980); Longio, Witholding Treatment from Defective Newborns: Who Decides and on What Criteria? 31 U. Kan. L. Rev. 377 (1983); Morgan, Quality of Life and the Malformed Child, 27 Oxford Medical School GazetTe 77 (1975); Robertson, Involuntary Euthanasia of Defective Newborns: A Legal Analysis, 27 STAN. L. Rev. 213 , 263-68 (1975), Robertson \& Fost, Passive Euthanasia of Defective Newborn Infants: Legal Considerations, $88 \mathrm{~J}$. PEDia'trics 883 (1976); Shapiro, Medical Treatment of Defective Newborns: An Answer to the "Baby Doe" Dilemma, 20 Hakv. J. Lecis: 137 (1983); Note, Birth Defective Infants: A Standard for Non-Treatment Decisions, 30 Stan. L. Rev. 599 (1978).

${ }^{5}$ In re the Treatment and Care of Infant Doe, No. GU8204-004A (Ind. Cir. Ct., Apr. 12, 1982), cert. denied sub nom., Infant Doe v. Bloomington Hospital, 464 U.S. 961, (1983) [hereinafter cited as Infant Doe.] See infra text accompanying notes 78-79.

${ }^{6}$ A tracheo-oesophageol fistula is a congenital abnormality involving an abnormal com. munication between the windpipe and the gullet which prevents normal digestion of food. Concise Oxford medical Dictionary 239 (Corgi ed. 1982).

${ }^{7}$ The Child Abuse Prevention and Treatment Act Amendments of 1984, Pub. L. No. 98-457, 98 Stat. 1749 (codified as amended at 42 U.S.C. $\$ 5101-05$ (1985)). [hereinafter cited as Child Abuse Amendments of 1984]; The Department of Health and Human Services Final Rule, 50 Fed. Reg. 14,878 (1985) (to be codified at 45 C.F.R. Part 1340) [hereinafter cited as the Child Abuse Rules]. 
bedside of newborns. ${ }^{8}$ The new federal law and regulations arose in response $^{9}$ to the recent frequency and wide breadth of decisions to withhold medically indicated treatment from handicapped newborns. ${ }^{10}$ Research into physicians' attitudes towards handicapped infants shows that a majority believe that feasible life-sustaining treatment should be withheld in

${ }^{8}$ See infra notes $100-129$ and accompanying text.

9 As to the full reasons, see Legislative History, Child Abuse Amendments of 1984, P.L. 98-457, 4 U.S. Code Cong. \& AD. News 2918, 2925-27 (1985) [hereinafter cited as "Legislative History."].

${ }^{10}$ The frequency of decisions to selectively withhold treatment from handicapped or malformed neonates has never been accurately discovered, probably because of the private way in which such decisions are often made. Dr. Robert E. Cooke estimated that thousands of decisions of this kind are taken each year in the United States. Medical Ethics: The Right to Survival 1974: Hearing on the Examination of the Moral and Ethical Problems Faced with the Agonizing Decision of Life and Death Before the Subcommittee on Health of the Senate Committee on Labor and Public Welfare, 93d Cong., 2d Sess. 26 (1974). It has also been reported that from January 1,1970 to June $30,1972,14 \%$ of the deaths in the intensive care nursery of the Yale New Haven Hospital resulted from non-treatment decisions. Duff \& Campbell, supra note 4. Professor John Lorber has reported the widespread use of non-treatment for over a decade. He has presented a breakdown of 848 infants born with a meningomyelocoele during 195868. These infants were treated with the best methods available at the time of their birth and $50 \%$ were still alive in $1972,81.4 \%$ of which were severely handicapped. Because of what Professor Lorber considered a poor prognosis, he developed a set of criteria for nontreatment, with selected patients receiving only normal nursing care and sedation from birth onwards. Lorber, supra note 4; Lorber, Early Results of Selective Treatment of Myelomeningocele: To Treat or Not to Treat, 53 Pediatrics 307 (1974).

For critical discussions of criteria for treatment selection see Black, Selective Treatment of Infants with Myelomeningocele, 5 Neurosurgery 334 (1979); Reid, Spina Bifida: The Fate of the Unireated-The Logical Outcome of Guidelines, 7 HAST. CEN. RPT. 16 (1977); Veatch, The Technical Criteria Fallacy, 7 HAST. CEN. RPT. 15 (1977).

Individual instances of selective non-treatment of handicapped neonates have also been reported in the medical literature and have sometimes been the subject of judicial decisions. Freund, supra note 4 (Down's Syndrome with duodenal atresia); Gustafson, Mongolism, Parental Desires and the Right to Life, 16 Perspect. Biol. \& Med. 529 (1973) (Johns Hopkin's case-Down's Syndrome with duodenal atresia), Maine Medical Center v. Houle, No. 74-145 (Super. Ct. Cumberland Co., Me., Feb. 14, 1974) (multiple malformities, brain damage and tracheo-oesophageal fistula); In re Obernauer (Juv. \& Dom. Rel. Ct. Morris County, N.J., Dec. 22, 1970) (Down's syndrome with duodenal atresia); Infant Doe, supra note 5; In re Phillip B., 92 Cal. App. 3,796, 156 Cal. Rptr. 48 (1979), cert. denied sub nom. 445 U.S. 949 (1980). Three cases of a similar kind have recently been reported in Europe. In re B. (A Minor) I WLR 1421 (1981) (Down's Syndrome with duodenal atresia); R. v. Arthur (Leicester Crown Ct., Nov. 5 , 1981) (physician acquitted of attempted murder of Down's Syndrome infant born with duodenal atresia where sedation was administered and no nourishment given); Dr. Willi Appel and Dr. Eva Maria Klotz (Crim. Ct., Munich, Landesgericht I. Schwargericht, ks 122 Js 4226/81, 24 March 1982) (physician convicted of second degree manslaughter and sentenced to 2-1/2 years imprisonment for giving lethal injection to infant born with massively deformed head and who was not expected to live). See Kaufman, Assessment of Euthanasia with Regard to Babies under Ethics and Criminal Law, 14 JuRestenzertung 481 (July 16, 1982). For further discussions of frequency and visability of decisions not to treat see Ellis, supra note 4 , at 398-401; Brown and Truitt, Euthanasia and the Right to Die, 3 OноO N.U.L. REv. 615, 634 (1976). 
certain circumstances. ${ }^{11}$ Studies indicate that social variables are the critical determinants for physicians' non-treatment preferences. ${ }^{12}$

The Child Abuse Amendment and Regulations represent an ethical/ legal watershed. By examining the first critical moments in human development, where decisions must be made to enable a handicapped neonate to live or to allow it to die, this essay proposes a jurisprudential/ethical standard against which such decisions can be made. This standard is then compared with the one set forth in the Child Abuse Amendment and regulations.

\section{MORAL ASSUMPTIONS UNDERLYING THE TREATMENT OF HANDICAPPED NEONATES}

Until relatively recently, society has eschewed explicit consideration of the ethics of treatment selection resulting in the death of handicapped infants. Selective non-treatment decisions, in practice, have devolved to the parents because the circumstances are often thought to be too sensitive, and the decision-making too complex, to be susceptible to any legal solution or general ethical formula. ${ }^{13}$

No family which has experienced the emotions surrounding conception, gestation and birth can fail to have deep empathy with the parents of a profoundly handicapped infant. ${ }^{14}$ During the period directly following

11 D. Crane, The Sanctity of Social life: Physicians' Treatment of Critically Ill Patients 35-87 (1975) (among the most important influences in non-treatment decisions were impact on family, potential usefulness to society or family and mother's attitudes). Todres, Krane, Howell \& Shannon, Pediatricians' Attitudes Affecting Decision-Making in Defective Newborns, 60 Pediatrics 197 (1977) (46\% felt Down's Syndrome infant with duodenal atresia should be operated upon); McKilligan \& Diller, Severe Congenital Abnormality in the Fetus and Newborn: Physician Attitude to Management (1975) (paper presented at the Annual Meeting of the Canadian Pediatric Association), reported in Affleck, Physicians' Attitudes Toward Discretionary Medical Treatment of Down's Syndrome Infants, 18 Mental RETARDaTION 79 (April 1980) (in an otherwise normal Down's infant, 17\% would want parents to do "everything humanly possible" to preserve life); Shaw, Randolph \& Manard; Ethical Issues in Pediatric Surgery: A National Survey of Pediatricians and Pediatric Surgeons, 60 PEDIATRICs 588 (1977) (one third of sample would not "acquiesce" in parental decision not to surgically correct duodenal atresia); Treating the Defective Newborn: A Survey of Physician's Attitudes, 6 Hast. CEN. RPT. 2 (Apr. 1976) (more than half sampled would not treat trisomy 18 newborns). See also Silverman, The Child as a Social Object: Down's Syndrome Children in a Paedriatric Cardiology Clinic, 3 Sociology of Healtu AND Illness 254 (1981) (excellent paper showing the ways in which physicians treat children with Down's Syndrome differently from other children with heart problems); Pilkington, Teaching Medical Students about Mental Handicap, 19 Devel. Med. CHILD Neurol. 652-58 (1977) (medical school teaching was not thought to facilitate appropriate knowledge of mental retardation).

${ }^{12}$ See generally, D. Crane, supra note 11.

${ }^{13}$ See, e.g., Duff, Counselling Families and Deciding Care of Severely Defective Children: A Way of Coping with 'Medical Vietnam,' 67 Pediatrics 315, 318 (1981); Williams, Down's Syndrome and the Duty to Preserve Life, 131 New L.J. 1020 (1981).

14 For discussions on the hardships parents face following the birth of a severely handicapped neonate see R. Darling, families Against Society: A Study of Reactions to 
birth, the family understandably desires privacy and wishes to avoid public scrutiny. The parents' assessment of the family's well-being, while deserving of recognition, is not, however, dispositive. Every child enters society with independent rights. Perceptions concerning the status and value of those rights have substantially influenced legal and ethical thought on the selective non-treatment of handicapped neonates. ${ }^{15}$ The discussion below examines three representative moral perspectives on the issue of selective non-treatment decisions.

\section{A. Vitalism}

Vitalist thought represents a core value of society. ${ }^{16}$ This philosophical

Children with Birth Defects 45-79 (1979); Duff \& Campbell, On Deciding the Care of Severely Handicapped or Dying Persons: With Particular Reference to Infants, 57 Pediatrics 487, 488 (1976); Fletcher, Attitudes Toward Defective Newborns, 2 HAst. Cen. Studs. 21 (1974); Kennell \& Klaus, Parental Reactions to the Birth of a Malformed Infant, 27 Oxford Med. SCHool Gazerte, 80 (1975); Shaw, Dilemmas of "Informed Consent" in Children, 289 New ENG. J. Med. 885, 886-87 (1973). For discussions of the effects on other children in the family see Bentovim, Emotional Disturbances of Handicapped Pre-School Children and Their Families-Attitudes to the Child, 3 BRIT. Med. J. 579 (1972); Cohen, The Impact of the Handicapped Child on the Family, 43 SociaL CASEWORK 137 (1962); Gath, The Effect of a Malformed Child Upon Other Children, 27 OxFORD MEd. School GazETTE 81 (1975).

15 There are arguments, both moral and legal, that human life must attain characteristics more complex and meaningful than simple existence before it should attract the attribute of "personhood." See Kuhse, supra note 4; Singer, supra note 4. Fletcher's indicators of personhood include cortical functioning and minimal intelligence, a sense of time, concern for others, and idiosyncracy. Fletcher, Indicators of Humanhood: A Tentative Profile of Man, 2 HAsT. CEN. RPT. 1 (Nov. 1972); Fletcher, Four Indicators of Humanhood-The Enquiry Matures, 4 HAST. CEN. RPT. 4 (Dec. 1974). Nelson refers to socialness, capacity to experience limitation and freedom, and religiousity or intentionality. J. NeLson, Human Medicine 19-24 (1973). Tooley focuses on self-consciousness, Tooley, Abortion and Infanticide, in Moral Problems in MediCine 297-317 (S. Gorovitz ed. 1976); Tooley, Abortion and Infanticide, 2 Phil. \& Pub. Afrairs 37,51 (1972).

The diversity in the factors which are presented as indicators of personhood suggests caution. See Johnson, Selective Non-Treatment of Defective Newborns: An Ethical Analysis, 47 Linacre QuarT. 39, 45-47 (1980). For a jurisprudential view that a monster is not a human being see G. Williams, The Sanctity of Life and the Criminal Law, 20-21, 31-35 (1957); Williams, supra note 13 at 1021 . For a medical view positing that where the prospects for "life" are minimal, infants should not be treated as persons see Lachs, Humane Treatment and the Treatment of Humans, 294 NEw ENG. J. MED. 838 (1976). This essay does not rely upon "definitional perceptions" of humanhood because of the dangers inherent in removing the concept of humanity from individuals or groups of individuals. Id. See also Ramsey, supra note 2, at 189-227; Bok, Ethical Problems of Abortion, 2 HAST. CEN. STuns. 33, 41 (1974); Robertson, supra note 4 , at $246-51$.

Definitional exemptions from personhood are sought to avoid an explicit breach of the core societal value that intentional taking of life is never justified. Havighurst, Blumstein \& Bovberg, Strategies in Underuriting the Costs of Catastrophic Disease, 40 Law \& ConTemp. Prob. 122,160 (1976). This removes the necessity of offering clear justifications for non-treatment decisions relating to "non-persons." See, e.g., Fletcher \& Bard, The Right to Die, AtLantic Monthly 39, 64 (Apr. 1968) (a father should feel no guilt over the death of a Down's Syndrome infant for guilt is only relevant to a person, and "a Down's is not a person.").

${ }^{16}$ While the various ideas that life is sacrosant are often vague and misleading, see, e.g., 
position holds that the preservation of individual human life is an end in itself, irrespective of the social, economic, or personal cost. The vitalist aggressively defends human biological existence. Life is so sacred to the extreme vitalist that the effort to sustain it should include the use of medical technology which is inordinately expensive, difficult to obtain, or rarely successful (i.e., so-called "heroic" or "extraordinary" measures). ${ }^{17} \mathrm{~A}$ more moderate vitalist position recognizes that decisions affecting individual human life are already made as a consequence of allocating scarce health care resources. Consequently, there is no logical rationale for providing extraordinary treatment for handicapped neonates when the same treatment would not customarily be used for patients with comparable medical needs. ${ }^{18}$ Under either position, all customary medical procedures to prolong or save a life must be used irrespective of the patient's handicaps.

The most defendable position of vitalists, therefore, is that life is the value which everyone-handicapped or not-would regard as paramount. Vitalist thought requires that medical treatment chosen for an otherwise healthy person must also be chosen for one with physical and mental handicaps, however severe. A particularly articulate statement of this "medical efficacy" approach was made in 1983 by a coalition of medical associations and advocacy organizations for disabled people:

Frankena, The Ethics of Respect for Life, in Respect For Life in Medicine, Philosophy, and the LAW 24 (S.F. BARKER ed. 1977), they are nonetheless deeply ingrained in Judeo-Christian society. Roman Catholic Bishops' Conference for England and Wales, The Times (London) Nov. 7, 1981, at 3, col. 1 (The right to life for all "innocent people" is totally independent of the wishes of others or the judgment of society. There is no difference whether the person is "in full vigour" or handicapped, whether their life is beginning or ending. But there is no moral obligation to undertake "major and dangerous" treatment when it will only briefly interrupt the onset of death); Moshe Tendler, a Professor of Talmudic Law, has stated that "a person who has but a few minutes to live is no less of value than a person who has 60 years to live ... a handicapped individual is a perfect specimen when viewed in an ethical context. The value is an absolute value. It is not relative to life expectancy, to state or health or to usefulness to society." H. Brody, Ethical Decisions in Medicine 75 (1981).

17 There has been much discussion between "ordinary" and "extraordinary," between "feasible" and "non-feasible," and between "conventional" and "unorthodox" medical treatment. See, e.g., In re Conroy, 98 N.J. 321, 486 A.2d 1209, 1234-35; Honey, Acts and Omissions, 5 J. Med. Erhics 143 (1979); Robertson, supra note 4, at 235-37. Some have argued that these traditional distinctions provide fruitful guidelines in determining the treatment of handicapped infants. Josen, Traditional Distinctions for Making Ethical Judgments, 1984 Ariz. Srate L.J., 661 (1984); Comment, Baby Doe Decisions: Modern Society Sins of Omission, 63 NEB. L. Rev. 888 (1984). Others cogently suggest that these distinctions are unclear in their application. Capron, Borrowed Lessons: The Role of Ethical Distinctions in Framing Law on Life-Sustaining Treatment, 1984 ARIz. STATE L.J. 647 (1984). For the purpose of this essay, treatment decisions for handicapped infants are measured against those for "normal" infants with similar medical needs. A conventional or feasible treatment is one which, given the potential efficacy and risks, would be administered to a non-handicapped infant.

${ }^{18}$ See Havighurst, Blumstein \& Bovberg, supra note 15, at 140-45. 
When medical care is clearly beneficial, it should always be provided. . . . Considerations such as anticipated or actual limited potential of an individual and present or future lack of available community resources are irrelevant. ... The individual's medical condition should be the sole focus of the decision. . . . In cases where it is uncertain whether medical treatment will be beneficial, a person's disability must not be the basis for a decision to withhold treatment. ${ }^{19}$

This approach has now found expression in the Child Abuse Amendments and was cited with approval in the proposed regulations promulgated by the U.S. Department of Health and Human Services. ${ }^{20}$

The considerable advantage of the vitalist position is its consistency of values and application in individual cases. It is the only formula which ensures complete equality in access to medical care to any person irrespective of handicap. Moreover, it is the only philosophic position which avoids the essentially unresolvable human choice of which lives are worth living. The treatment decision is based solely upon a medical judgment of the patient's physical condition and the availability of treatment to remedy that condition. While such decisions are often themselves subjective, they are equally applicable to all patients.

A general ethical principle should not be accepted simply because it can be applied consistently to individual cases. Vitalism represents the easiest social choice precisely because it avoids the need for society to make any choice among human lives. Choices, however, do have to be made because there are circumstances where individuals may reasonably prefer death to a life rendered unendurable by totally incapacitating illness or disability. ${ }^{21}$ This is true regardless of the chronological age of the patient. ${ }^{22}$

\section{B. Social Utilitarianism}

The other end of the philosophical spectrum is social utilitarianism. ${ }^{23}$ Proponents of the doctrine would balance the potential productivity of the life to be preserved with the social and economic costs of the treatment.

\footnotetext{
19 American Academy of Pediatrics, Joint Policy Statement Principles of Treatment of Disabled Infants, 73 Pediatrics 559, 561 (1984).

${ }^{20}$ Child Abuse and Neglect Prevention and Treatment Program: Notice of Proposed Rule Making, 49 Fed. Reg. 48161, 48161-62 (1984) [hereinafter cited as "Child Abuse Proposed Rules"].

21 The courts have already recognized that in certain circumstances, a decision may be made on behalf of an incompetent adult to withhold life-sustaining treatment. See infra notes 66-70 and accompanying text.

22 As to the case law regarding the medical treatment of children in the absence of parental consent, see infra notes 49-77 and accompanying text.

${ }^{23}$ For a comprehensive assessment of utilitarianism in the context of treatment decisions for the newborn see Robertson, supra note 4, at 252-62.
} 
Thus, not only would the limited social and economic potential of a severely handicapped infant weigh against treatment, but also the inordinate cost of the treatment and long term domestic or institutional care would be relevant. Social utilitarianism, therefore, would result in treatment for a specific physical condition being withheld from a severely handicapped infant, even if the same treatment would be given to an otherwise healthy infant. The critical factors in the treatment decision are not the efficacy of the treatment or the remediability of the physical condition, but the social and economic cost to others resulting from treatment and lifelong care.

If applied to all age groups, social utilitarianism would imperil the lives of many ill-functioning people who are regarded as economically and socially non-productive. Since each of us may reach a point in our lives when our "usefulness" to society could be questioned, self-interest alone should bar wide-spread acceptance of social utilitarianism. Utilitarian ideals would also be unacceptable to people who believe that human life should not be measured by its utility to others but by its intrinsic value for the individual.

Under utilitarian thought, the decision to terminate life does not include consideration of the choice the patient would make if competent. If we accept that virtually no competent person would make his or her social value, as perceived by others, the major determinant in deciding whether or not to seek medical care, it is difficult to accept the logic of applying a standard based upon cost and social worth in relation to any human life.

\section{Quality of Life}

The term "quality of life" has been introduced into Anglo-American jurisprudence ${ }^{24}$ and by commentators ${ }^{25}$ to justify the withholding of medi-

24 Courts have been reluctant expressly to adopt a "quality of life" criterion and have been careful not to demarcate a class of individuals, such as the mentally retarded or senile, as deserving a lower standard of legal protection. Yet several courts have made implicit assessments of personal quality of life and normalcy in coming to their decisions. It is helpful to distinguish between two groupings of cases to determine whether a court is actually employing a "quality of life" standard. The first are cases which are decided principally by an assessment of the medical benefits, risks and adverse effects of the treatment in question. (Is there a "substantial chance for cure?" Are there "medically effective alternative treatments?") Here, the court's decision follows directly from the medical assessment. The principal finding is factual, i.e., whether a medical consensus exists that the treatment is indicated and that there are no medically recognized alternatives. Given this finding of fact courts will usually come to the same decision, irrespective of the legal standard applied. See, e.g., Custody of a Minor, 375 Mass. 733, 379 N.E.2d 1053 (1978), aff'd, 378 Mass. 732, 393 N.E.2d 836 (1979) (order permitting chemotherapy for minor patient suffering from acute lymphocytic leukemia over parental objection; court found chemotherapy offered a "substantial chance for cure" and the alternative treatment of metabolic therapy was medically ineffective and poisonous); In $r e$ Hofbauer, 65 A.D.2d 108, 411 N.Y.S.2d 416 (1978), aff'd, 47 N.Y.2d 648, 393 N.E.2d 1009, 419 N.Y.S.2d 936 (1979) (a child suffering from Hodgkins Disease whose parents failed to 
cally indicated treatment for severely handicapped infants whose life would be so bereft of enjoyment as not to be worth living. As under social utilitarian thought, medically effective treatment, even if available and efficacious for an otherwise normal infant, could be withheld based upon broader consideration of the infant's handicaps. The relevant factors under a "quality of life" assessment relate not to social worth or to economic cost, but to the infant's potential for human contentment.

It is difficult to argue with the premise underlying the "quality of life" position, for there must come a point for most of us where life is so devoid of meaning and contentment that it is not worth living. As a philosophic position, its weakness is that the factors which would justify forsaking

follow attending physician's recommendation for treatment by radiation and chemotherapy, but rather placed child under care of licensed physician advocating nutritional or metabolic therapy, was not a neglected child; court found parents had justifiable concerns about deleterious effects of radiation and chemotherapy, that alternative treatments were controlling child's condition, and that conventional treatments would be administered if child's condition so warranted); Ex rel Cicero, 101 Misc. 2d 699, 421 N.Y.S.2d 965 (Sup. Ct. 1979) (guardian appointed to consent to corrective surgery for infant born with meningomyelocele. The court found child unlikely to live beyond 24 months without surgery and that surgery would permit child to walk with leg braces and to have "normal intellectual development" with little future risk of mental retardation.).

The cases cited above should be distinguished from those where the court is influenced not only by its findings of fact as to the choices of treatment, but also by the person's wider characteristics, including his or her potential for intellectual and social functioning. See, e.g., In re Phillip B., 92 Cal. App. 3d 796, 156 Cal. Rptr. 48 (1979), cert. denied sub. nom, 445 U.S. 949 (1980) (court declined to order life-prolonging heart surgery for minor suffering from congenital ventricular septal heart defect. The trial court found corrective surgery to be medically indicated with 5 to 10 per cent mortality rate but noted that the child had Down's Syndrome; the judge commented that he personally could not handle it "if it happened to me."); Infant Doe, supra note 5 (court order barring doctors from providing nourishment or treatment for Downs Syndrome infant born with a deformity in the stomach wall which prevented food being digested; the condition could have been corrected by surgery which was serious but considered within the range of standard medical practice); In re Spring, 380 Mass. 629, 405 N.E.2d 115 (1980) (court approval for removal of 78 year old patient from kidney dialysis, probate court found patient to be senile and incapable of restoration to a "normal, cognitive, integrated functioning existence"); Superintendent of Belchertown State School v. Saikewicz, 373 Mass. 728, 370 N.E.2d 417 (1977) (authorization for non-treatment of 67 year old mentally retarded ward suffering from acute myeloblastic monocytic leukemia; probate court found chemotherapy was life-prolonging and was treatment of choice, but patient's profound retardation was a significant issue in the case); In re Conroy, 98 N.J. 321, 486 A.2d 1209 (1985) (nursing home resident with severe and permanent mental and physical defects and limited life expectancy could have life-sustaining treatment withdrawn in certain circumstances).

If one were to remove the wider "quality of life" element from the facts of these cases the results would appear anomalous and, in some instances, clearly erroneous. It is highly probable that the court in each of these cases would have opted to prolong a life it considered worth living. See Annas, Quality of Life in the Courts: Early Spring in Fantasyland, 10 HAST. CEN. RPT. 9 (Aug. 1980). A further, albeit less apparent, instance of a quality of life assessment occurred in In re Quinlan, 70 N.J. 10, 355 A.2d 647, cert. denied, 429 U.S. 922 (1976) and its progeny. See infra note 66. See also, Annas, Reconciling Quinlan and Saikewicz: Decision-Making for the Terminally Ill Incompetent, 4 AM. J.L. \& MED. 367 (1979).

${ }^{25}$ See, e.g., Goldstein, supra note 4, at 651-61; Williams, supra note 13, at 1020-21. 
continued life are seldom, if ever, specified. If one accepts that continued life is not in the infant's interest, then those who make this decision must be clear about the criteria to be adopted. Yet the basis for identifying and measuring those interests under a "quality of life" standard is unclear.

In practice, the term "quality of life" often is not used as a coherent moral theory which defines with any certainty which handicapping conditions should or should not be treated. Rather, the term is employed as a signal by those who believe that selective non-treatment decisions are too delicate and complex to be governed by any coherent legal or ethical standard. Accordingly, most of those who advocate a "quality of life" assessment seek to maintain the decision-making process within a confidential doctor/patient framework.

\section{Proposed Moral Standard Based Upon Personal Interests}

Decisions which intimately affect human life require resolution within a framework of public morality which finds its expression and sanction in the law. The class of neonates subject to selective non-treatment decisions must be carefully and narrowly defined. It is important to distinguish, insofar as possible, those grave and exceptional cases where the neonate irremediably lacks the capacity to live a recognizable human life from those situations where the judgment is actually based upon comparative social worth. Furthermore, there should be some discernible moral consensus for the substitute decision to be made, i.e., there should be a reasonable certainty that a competent individual would not choose to continue life in the circumstances presented. The intention here is to propose criteria which recognize the personal interests of the ward in continuing life, without basing his or her comparative social and economic worth upon a measure of "normalcy."

The following categories cover the entire set of circumstances where selective non-treatment decisions may legitimately be made. Where the specific and narrowly conceived criteria are met there is a choice to be made whether to treat the infant. No such choice would arise in any other context. In cases which do not come within the narrow criteria proposed, the same "medical feasibility" standard used for all patients would apply, i.e., treatment would depend upon a purely medical judgment as to the efficacy of the proposed treatment, its alternatives, and risks. Outside the narrow criteria proposed, the responsibility of the guardian of any child, whether handicapped or not, to provide medical treatment grows stronger as the treatment of choice becomes clearer and, more importantly, the risk to the child of not having treatment becomes greater. 


\section{The Neonate is not Conscious and Sapient}

Judicial principles governing treatment for the incompetent patient have been derived from positions of extremity. The standard in Quinlan ${ }^{26}$ and its progeny ${ }^{27}$ for non-treatment decisions which do not require judicial approval should apply to any incompetent patient, irrespective of the stage in chronological human development. ${ }^{28}$ Thus, where an infant is permanently comatose and has no reasonable possibility of returning to a cognitive, sapient state, aggressive medical treatment would not be required. Moreover, since the decision is exclusively dependent upon a reliable prognosis, it should lie with the guardian and medical professionals. Confirmation of the prognosis by other physicians through a hospital review board or by concurring medical opinions would be a reasonable prerequisite to the decision-making process.

Adoption of a Quinlan standard would quell some of the concerns of the medical profession by allowing the physician, in conjunction with the guardian, to make decisions in exceptional cases without recourse to prior judicial approval. Most appropriately, this standard could be followed in cases where the infant is inflicted with abnormalities incompatible with sapience, i.e., where the abnormality, disease or damage to the central nervous system, especially the brain, is so gross as to make the attainment of a cognitive sapient state improbable. A reliable prognosis meeting a Quinlan standard could be made and confirmed in infants presenting with such conditions as anencephaly, ${ }^{29}$ hydranencephaly ${ }^{30}$ and extreme forms of

${ }^{26}$ In re Quinlan, 70 N.J. 10, 355 A.2d 657, cert. denied, 429 U.S. 922 (1976).

${ }^{27}$ See infra note 66.

${ }^{26}$ It has been suggested that the Quinlan criteria would not apply in the case of severely defective newborns because the infant's quality of life seems more hopeful. Ellis, supra note 4 , at 405-07. It is difficult to see what hope the life of a permanently comatose infant possibly promises to offer. Courts could not reasonably apply special protective standards for the newborn who has no reasonable potential for attaining a cognitive sapient existence. In one case, for example, the Massachusetts Supreme Court ordered that no extraordinary resuscitative measures should be taken in the case of a conscious and cognitive infant who did not have a life expectancy beyond one year. Custody of a Minor, 385 Mass. 697, 434 N.E.2d 601 (1982).

2:" Anencephaly is a partial or total absence of the brain. See Hamilton, Hutchison, Fraser, Kooh \& Farquhar, Disorders of the Endocrine Glands, in Texтвоoк of Paediatrics $1128-29$ (J. Forfar \& G. Arneil 3d ed. 1984). One distinguished pediatrician refers to anencephaly as "a lethal malfunction in which the vault of the skull is absent and the exposed brain is amorphous. Between 75 and 80 percent of these infants are stillborn and the remainder succumb within hours or a few days after birth." Bell, Abnormalities in Size and Shape of the Head, in Diseases of The Newborn 716-17 (A. Schaffer \& M. Avery 4th ed. 1977).

${ }^{30}$ In hydranencephaly the bulk of the cerebral cortex is replaced by fluid. See Brown, Stark, Minns, Aicardi, Shaw, Steer, Townsend, Macdonald, Forfar and Fulford, Disorders of the Central Nervous System, in Textвook of PaEdiatrics 704 (J. Forfar \& G. Arneil 3d ed. 1984) [hereinafter cited as Disorders of the CNS]; Bell supra note 29, at 733-35; L. Holmes, H. Moser, S. Haldorsson, C. Mack, S. Plant, \& B. Matzilevich, Mental Retardation: An Atlas of Diseases with Associated Abnormal:ties, 204 (1972) [hereinafter cited as Mental RETARDATION]. 
hydrocephalus. ${ }^{31}$ In such cases, withholding treatment would be legally and ethically acceptable. ${ }^{32}$

2. The Potential for Dealing with, and Responding to, Sensory Information and Experiencing Thought is de minimis

Quinlan and its progeny involved patients who were in chronic and irreversible vegetative states. Arguably, the Quinlan standard is too narrow to include many neonates who are grievously afflicted by multiple physical and mental handicaps. It may be desirable to extend the Quinlan standard to cover the neonate who is conscious and sapient, but whose potential for responding appropriately to sensory information or experiencing thought is de minimis, i.e., those infants whose response to their environment is primitive and broadly reflexive. Infants who may come within this category include those born with a progressive, degenerative disease of the brain such as infantile leucodystrophy, ${ }^{33}$ with certain severe chromosome disorders such as Trisomy $13,{ }^{34}$ with gross and imminently life threatening abnormalities such as the total absence of kidneys, ${ }^{35}$ and with fully documented severe brain damage following asphyxia, hemorrhage, or infection. ${ }^{36}$ Most infants with afflictions such as these have massive physical

31 The term hydrocephalus encompasses a group of conditions associated with ventricular enlargement. Hydrocephalus implies the presence of an increased quantity of cerebrospinal fluid under increased pressure. Abnormal enlargement of the head often occurs when hydrocephalus begins prenatally (as with babies born with myelomeningocele) or in the newborn period. Newborns with very extreme forms of hydrocephalus, especially if complicated by other abnormalities or by CNS infection may not have the potential to lead a conscious sapient existence. See Bell, supra note 29, at 725-33; Disorders of the CNS, supra note 30 , at 700-04.

${ }^{32}$ There are cases where the medical response at birth often is not to take special resuscitation measures. More difficult issues arise after extrauterine life has been established but where there may be little potential for a fully cognitive sapient existence.

${ }^{33}$ Leucodystrophies and leucoencephalopathies are disorders of myelination in a developing young brain. In Krabbe's Leucodystrophy, for example, at about three months babies become fretful, vomit and lose weight. There is optic atrophy and eventual blindness. Fits and spasms occur, accompanied by the inability to swallow, and finally a generalized flaccid paralysis. Death occurs within two years and frequently before one year of age. See Disorders of the CNS, supra note 30, at 781-82; Mental Retardation, supra note 30, at 18 .

${ }^{34}$ Trisomy 13 is a chromosome defect. The baby is low birth weight, microcephalic, and commonly has abnormalities of the ears, eyes, limbs and heart. All are severely mentally retarded, with marked hypertonia and myoclonic spasms. Half of these infants live beyond one month, more than half the remainder die before three months, and only five per cent survive beyond three years. See Bell, supra note 29, at 917-18; Bain \& Ellis, Chromosomal Disorders in Textвook of Paediatrics $912-13$ (J. Forfar \& G. Arneil 3d ed. 1984); Mental. Retardation, supra note 30 , at 164 .

${ }^{35}$ Such an infant would rapidly die without dialysis or kidney transplant, neither of which are done for neonates. While the brain may be normal, the metabolic abnormalities would soon produce coma and death.

${ }^{36}$ Infants, for various reasons, may suffer from hemorrage, asphyxia, or infection at birth, generally resulting in grievous life long injuries. See Bell, Perinatal Insults to the Brain and Spinal Cord in Diseases of The Newborn 703-15 (A. Schaffer \& M. Avery 4th ed. 1977). 
malformations and will subsist at the most rudimentary level of consciousness for their entire lives. Qualitatively, it is difficult to differentiate such infants' existence from those who are comatose. The plight of infants in the former category may indeed be worse; because they have some rudimentary consciousness, they may also experience pain and discomfort. There can be no legal or ethical justification for preserving such lives through intervention where no prospect of minimal human functioning exists. It is essential that the prognosis be certain; therefore, when difficult cases arise in the determination of a "severely impaired response potential,"37 additional professional guidance should be sought. ${ }^{38}$

\section{The Neonate is Terminally Ill and in the Process of Dying}

Difficulties arise in extending the preceding two standards to cases where it is less obvious that a newborn or other incompetent person should be allowed to die. The literature shows that selective non-treatment decisions in pediatric practice extend well beyond the circumstances envisaged under the two standards described above. ${ }^{39}$ The two standards, which are exceedingly narrow in scope, are essentially concerned with infants who could have no response, or only the most primitive reflexive response, to stimulation; these children lie virtually motionless in their beds, essentially unaware of the world around them.

The question arises whether there is ever a justification for not treating handicapped infants who have a potential to minimally engage their physical environments, for example, by sitting up, turning the head to follow a light, reacting to sounds, or purposefully grasping an object. Children with some or all of these abilities will not fall within either of the two standards

${ }^{37}$ For a discussion of persistent states of minimum cognition in incompetent adult patients, see Jennett \& Plum, Persistent Vegetative State After Brain Damage: A Syndrome in Search of a Name, I LANCEr 734 (1972).

${ }^{3 *}$ It is often difficult to detect, only hours or days following birth, what the neonate (particularly if severely defective) is experiencing of the outside world or what he is likely to experience in the future. It'seems imperative for the medical profession to arrive at a code to guide attending pediatricians' prognoses under these circumstances. Certain forms of objective evidence should be required before an infant may be declared to have severely impaired response potential. For example, the code might refer to the absence of active response to food, noise, sight, rocking and cuddling or other human stimulation; the prognosis, however, would have to refer to maximum future potential, as opposed to existing capabilities.

The use of statutory or judicial standards in conjunction with medical guidelines has an analogy with brain death. See generally Lovato v. District Court, 198 Colo. 419, 601 P.2d 1072, 1076 n. 6 (1979); Schneck, Brain Death and Prolonged States of Impaired Responsiveness, 58 DEN. L. J. 609,618-25 (1981). A similar code of guidance is needed to assist in the reliable identification of severely impaired response potential in neonates. For a discussion of the state of consciousness of a newborn and his predictable directed responsiveness when in a social interaction with a nurturing adult or when receiving attractive auditory, tactile or visual stimuli, see Brazelton, Neonatal Behavior and its Significance in Diseases of THE Newborn, 37-56 (A. Schaffer \& M. Avery 4th ed. 1977).

3" See supra notes 10-11 and accompanying text. 
discussed above. It is suggested, however, that in some circumstances medically indicated treatment would not serve the interests of an infant who is terminally ill and in the process of dying. This does not mean that death be imminent in days or weeks, but it must be unavoidable within months or several years at most. To reach such a decision it must be demonstrably clear that the pain and suffering associated with proposed life-sustaining treatment would be wholly disproportionate to the infant's potential for achieving any personal satisfaction or human interaction.

This category differs from the previous two in that its parameters are less amenable to precise delineation. If an infant has the potential to minimally engage in his or her world, there is no single characteristic which would clearly indicate that feasible treatment should be withheld. Nevertheless, the absence of any single dispositive factor does not, and should not, mean that courts can avoid their traditional responsibility for determining where the interests of the ward lie; those interests may require non-treatment in circumstances where it is reasonably likely that a competent person would make the same choice.

The benchmark for this category is a clear prognosis of death within months or several years at most. ${ }^{40}$ While terminal illness is the primary justification for the non-treatment of infants falling within this category, it is not a sufficient justification in itself. There are a cluster of additional characteristics which are relevant:

a. severe or progressively increasing pain and suffering;

b. severely impaired cognitive and learning potential which precludes social or human interaction;

c. multiple physical disabilities preventing any significant voluntary movement; and

d. multiple severe impairments or absence of sense perception, particularly sight and hearing.

A balancing process, made on a case by case basis, would determine whether an infant falls within this non-treatment category. Each element is an important part of the balance and objective medical evidence on each factor should be sought. Clear medical evidence indicating that the infant is afflicted with most or all of the cluster items would warrant a nontreatment decision; inconclusive or contrary medical evidence would favor administration of feasible treatment. The presence or absence of any

${ }^{40}$ A feature of the case law relating to selective non-treatment decisions is the very short life expectancy of the incompetent patient, together with the minimal potential for learning and development. See, e.g., Custody of a Minor, 385 Mass. 697, 434 N.E.2d 601 (1982); In re Spring, 380 Mass. 629, 405 N.E.2d 115 (1980); Superintendent of Belchertown State School v. Saikewicz, 373 Mass. 728,370 N.E.2d 417 (1977). Severely limited life expectancy is taken to mean that the neonate would not be expected to live beyond infancy, usually under 24 months. 
one of the cluster items would not be conclusive. Infants who might fall within this category for non-treatment include those born with such chronic progressive disorders as Tay Sacks disease, ${ }^{41}$ Menkes Syndrome, ${ }^{42}$ and severe chromosomal disorders such as Trisomy $18 .{ }^{43}$

One of the touchstones of the balancing process is the potential for human satisfaction from social or interpersonal interaction. It is assumed that the potential for such satisfaction weighs heavily on the scale of human endeavor. The potential for developing communication skills and other complex patterns of behavior would be indicators favoring efficacious treatment. For example, it could not be said with confidence that efficacious treatment should be withheld from an infant with a non-correctable heart condition who will have normal cognitive and emotional development for some two or three years. Such a child will experience many valuable aspects of life; the uncertainty of any prediction that the child's life would be intolerable is too great to justify non-treatment.

This standard for non-treatment, then, would not apply to infants born with conditions such as Down's Syndrome ${ }^{44}$ or spina bifida, ${ }^{45}$ without

\footnotetext{
41 In this condition there is a storage of ganglioside GM on the brain and in the viscera. As a result, the brain may be very large (megalencephaly) but if the infant lives longer than 18 months, secondary degeneration in white matter, and extensive cell loss, may result in cerebral atrophy and a small brain. The disease occurs primarily in Ashkenazi Jews. The clinical picture is described infra in the text accompanying notes 60-61. See also Disorders of the CNS, supra note 30, at 775; Birth Defects Compendium 486-87 (D. Bergsma ed. 1979); Mental Retardation, supra note 30 , at 62 . A similar disease is infantile GM1 Gangliosidoses where there is a generalized storage of GM 1 ganglioside. The end result is blindness, deafness and decerebrate rigidity with death from 2 months to 3 years. See Disorders of the CNS, supra note 30, at 775-76; Mental. Retardation, supra note 30, at 22.

${ }^{42}$ Menkes Syndrome, also known as steely-hair or kinky hair disease, is inherited in an $\mathrm{X}$-linked recessive fashion. Within a few weeks drowsiness, lethargy, hypotonia, and feeding difficulties appear; hypothermia is common, as are progressive developmental retardation, spasticity, seizures, variable muscle tone and immobility. The infant develops a decerebrate posture and appears unaware of his surroundings. Death usually occurs in the first or second year. Buist, Kennaway, Kelly, Lloyd, Fernandes, Hume \& Forfar, Metabolic Disorders, in Textвook of Paediatrics 1235-36 (J. Forfar \& G. Arneil 3d ed. 1984); Mental ReTardation, supra note 30, at 100; Birth Defects Compendium, 694-95 (D. Bergsma ed. 1979).

${ }^{43}$ Apart from Trisomy 21 (Down's Syndrome), trisomy of chromosome 18, also called Edward's Syndrome is probably the most commonly encountered autosomal trisomy. Many affected babies are of low birthweight, with a small elongated head and a flattening of the forehead down to the nose. Cardiac and renal anomalies are invariably present. Thirty percent die by 1 month, 50 percent by 2 months, 70 percent by 3 months, 90 percent by 1 year and 99 percent before age 10 . Survivors are profoundly retarded in motor and intellectual development. None have been able to walk or talk. Bain \& Ellis, Chromosomal Disorders in Textbook of Paediatrics 910-12 (J. Forfar \& G. Arneil 3d ed. 1984); Mental Retardation, supra note 30, at 160; Birth Defects Compendium 201-202 (D. Bergsma ed. 1979).

${ }^{44}$ Down's Syndrome is a chromosomal defect which usually results in mental retardation. Because there are three number 21 chromosomes instead of the usual two, this condition has been given the medical classification of Trisomy 21. See generally Craft, Chromosomal Abnormalities, in Tredgold's Mental Retardation 52-54 (M. Craft 12th ed. 1979). The cumulative
} 
any accompanying irremediable condition falling within one of the narrow standards previously proposed. Any neonate who, with treatment, can expect to live and progress through infancy into childhood, ${ }^{46}$ and who is capable of human feeling and social response, should be sustained by efficacious medical treatment. It is the responsibility of the state as parens

results of scientific, psychological and educational research in the last decade have demonstrated that the potential of infants born with a recognized primary syndrome or condition such as Down's Syndrome has been seriously underestimated. With systematic training, education, and stimulation during the early years of development, the majority of Down's Syndrome children without any accompanying irremediable disability can expect to develop basic social and motor skills, including language, mobility, and, often, literacy. These children possess the potential for social interaction, family integration and the formation of peer relationships. The increased knowledge of early development and a heightened awareness of the importance of education and normal emotional interchange has considerably altered the conception of a Down's Syndrome child from that of a passive and unresponsive recipient of information to a person capable of active learning and progressive human development. Down's Syndrome children are as diverse in their desire and ability to participate in social activity and in the enjoyment of life as other children. See Rynders, Spiker \& Horobin, Underestimating the Educability of Down's Syndrome Children: Examination of Methodology Problems in Recent Literature, 82 Am. J. Ment. DEF. 440 (1978); Clarke \& Clarke, Mental Retardation and Behavioral Change, 30 BRIT. Med. Bull. 179 (1974); Drash, Increasing Intelligence and Speech in Down's Syndrome Infants: A Three to Five Year Follow-up, 5 Down's Syndrome: PaPers and Abstracts for Professionals 2 (1982); See Cunningham, Early Stimulation of the Severely Handicapped Child in Tredgold's Mental Retardation 82 (M. Craft 12th ed. 1979); Kirman, Growing up with Down's Syndrome, BRIT. J. Hosp. MEd. 385 (April 1980); Cooke, Heron, Heward \& Test, Integrating a Down's Syndrome Child in a Classroom Peer Tutoring System: A Case Report, 20 Mental Retardation 22 (1982); Sinson \& Wetherwick, The Behavior of Children with Down's Syndrome in Normal Playgroups, 25 J. Ment. Def. 113 (1981); Harris, Physical Therapy and Infants with Doum's Syndrome: The Effects of Early Intervention, 42 ReHabiLitation LuTERATURE 339 (1981). For a review of the literature on the capacity for growth and development of Down's Syndrome children and adults see S. Pueschel \& L. Steinberg, Down Syndrome: A Comprehensive Bibliography 349-59 (1980).

${ }^{45}$ Spina bifida is a developmental defect in which the newborn baby has part of the spinal cord and its coverings exposed through a gap in the backbone. The symptoms may include paralysis of the legs, incontinence, and mental retardation from the commonly associated brain defect, hydrocephalus. Spina bifida is associated with abnormally high levels of alphafetoprotein in the amniotic fluid surrounding the embryo. The condition can be diagnosed at about the 16 th week of pregnancy by a test on the amniotic fluid (amniocentesis). See Disorders of the CNS, supra note 30; Sylvester \& Craft, Acquired Conditions, in Tredgoln's Mental Retardation 115, 118-19 (M. Craft 12th ed. 1979); Ellis, supra note 4, at 395-96. Professor Lorber reports that of the first 41 spina bifida infants selected for non-treatment (food, water and nursing care only) none survived beyond eight months and $60 \%$ were dead before they reached one month of age. Lorber, supra note 4, at 55 . Elsewhere he reports that of his selective non-treatment cases, $80 \%$ die within three months and only four percent are still alive before one year. Lorber, The Management of Spina Bifida, 27 Oxford MEdical. School Gazette 76 (1975).

${ }^{46}$ One of the most difficult cases is illustrated by Pelizaeus-Merzbacher disease which is a more chronically slow progressive disorder. The speech is at best limited to a few words; usually only grunting sounds are made. By three to six years of age many patients are immobile with scissoring of their legs and flexed arms. Optic pallor and loss of vision develops late in the course of the disease. Dementia, a masklike facial expression, and seizures usually occur. Terminally, the patients have difficulty in swallowing, vomit frequently, and are incontinent. Mental Retardation, supra note 30, at 75. 
patriae to enrich the life of such a child by providing the treatment, care, and habilitation necessary to maximize the child's development. This usually requires the placement of the infant in normal surroundings that provide full opportunities for love, education and general stimulation.

This should be the area of common agreement at the intersection of law, medicine, and ethics: a handicapped infant who has the potential for human satisfaction within his or her own limited orbit of existence has the right to the nurturing and medical care necessary to achieve that potential and to develop to maturity.

\section{E. Prior Judicial Review and the Proposed Standards}

A question of substantial importance to the health care community, as well as to parents, is whether the courts will require prior judicial review of any decision to withhold efficacious treatment. Courts have adopted varying procedures for exercising an incompetent person's right to refuse medical treatment. ${ }^{47}$ While a full resolution of this question is beyond the scope of this essay, some general guidelines in relation to the criteria proposed above are offered.

Where there are societal, as opposed to purely clinical, issues to be determined, it is for the courts to lay down general principles to be applied by the health care profession. The question of whether a treatment is indicated is a matter for the medical profession; whether a medically indicated treatment is to be withheld is a social/ethical matter for resolution in the courts. Our common law system operates on the basis of general rules laid down by a court to be followed without the need for judicial approval in every case. Parents and health care professionals can be relied upon to follow a common set of rules laid down in advance by the courts.

Courts should strive to develop clear and objective principles which command a wide social consensus. If clear principles can be formulated, the practical implementation can effectively be left to the medical profession. Already such forms of social consensus and objective criteria are present in policies concerning brain death and the treatment of irreversibly comatose patients. Here most courts have developed procedures for nontreatment decisions which do not require their participation. ${ }^{48}$

It is suggested that the first two categories proposed in this essay are instances where non-treatment decisions could be made without prior review by a court. Objective signs designate those infants who are "irreversibly comatose" or suffer from a "severely impaired response potential." There exists, moreover, an increasing social consensus that a passive, non-

${ }^{47}$ See infra note 68.

${ }^{48}$ See, e.g., In re Quinlan, 70 N.J. 10, 355 A.2d 647, cert. denied, 429 U.S. 922 (1976); In re Conroy, 98 N.J. 321, 486 A.2d 1209 (1985). 
responsive, non-interactive life is not worth living. Accordingly, if there is agreement between the parents and the health care personnel, it is difficult to see any need for judicial approval prior to making the decision to withhold treatment. Both categories would require reasonably certain prognoses corraborated, for example, by a hospital medical committee.

By clearly enunciating the circumstances where prior judicial approval for non-treatment decisions is not required, courts would promote family privacy and avoid public scrutiny of intimate personal decisions, give clear notice to parents and professionals of their legal obligations to treat handicapped neonates, and minimize the time and resources expended in litigating these issues.

Judicial review prior to a selective non-treatment decision is warranted only in two circumstances:

1) where there is a conflict of evidence or views which requires independent resolution, e.g., where there is no clear medical consensus as to the prognosis or there is disagreement between the patient or the patient's guardian and health care personnel on the appropriateness of treatment;

2) where there is a conflict over the application of accepted legal principles. Where the facts fit clearly within objective criteria previously laid down by a court, prior judicial review is not warranted. The courts are only beginning to develop the broad concept of "best interests" into narrow standards which can be objectively applied to diverse factual situations. Therefore, the ideal scenario in which the facts can be fully squared with judicial precedent will not soon occur in relation to many situations of death and dying. Were the courts to adopt the cluster of factors proposed here, they would still be expected to insist upon prior review, except in cases fulfilling most or all of the cluster criteria.

\section{JURISPRUDENCE RELATING TO SELECTIVE NON-TREATMENT DECISIONS}

\section{A. The Traditional "Best Interests" Principle}

If the parents wish that their handicapped child should be helped to live, there is no greater legal or moral imperative which should override that decision. It is, however, also within the parents' discretion to decide that they do not wish to rear a handicapped child. The extent of parental autonomy regarding an unwanted offspring thus raises difficult questions. Such a decision traditionally results in state intervention. Child welfare agencies generally prefer to seek adoptive or foster care in the community, thus placing the interests of the handicapped infant on the same level as those of the "normal" infant. However, if the parents do not want the child, under what circumstances do they have the legal prerogative to decide that it shall not live? 
A perennial source of discourse in family law concerns the point at which an exercise of parental choice is so harmful to the child as to require state intervention. ${ }^{49}$ The common law view of the parental function was based upon duties owed to parents by their children; parents had natural rights over the child which were considered to be in the nature of a property interest. ${ }^{50}$ This position maximized parental choice and sometimes verged upon permitting unfettered parental autonomy. The law still favors those parental choices which promote family integration, privacy, and the child's need for continuity of relationships. Conforming to these values, Anglo-American jurisprudence espouses the principle of minimum public intervention.

The law, then, allows parents a considerable "margin of appreciation" to rear and nurture their children. The law vests in parents reciprocal rights and responsibilities to raise their children to maturity and to make reasonable misjudgments along the way. There is no jurisprudential principle requiring parents to maximize a child's developmental potential or happiness, or to prevent any insignificant harm from coming to the child. While no unequivocal judicial boundaries have been set to determine the precise extent of parental autonomy, the modern view does not extend parental authority without limit. Parents have no legal right to make decisions which cause serious irreversible harm to their children; there is no judicial principle or statutory provision making handicapped children an exception.

Courts have accepted the need for public intervention where parental decisions about medical care threaten significant potential harm to the child. ${ }^{51}$ The State's decision to intervene depends principally upon the

${ }^{49}$ Compare Goldstein, Medical Care for the Child at Risk: On State Supervention of Parental Autonomy, 86 YALE L.J. 645 (1977) (strong presumption in favor of parental autonomy) with Dickens, The Modern Function and Limits of Parental Rights, 97 L.Q.R. 462 (1981) (parental function is limited to protection of children against physical, psychological, social and moral harm). See also Horwitz, Of Love and Laetrile: Medical Decision-Making in a Child's Best Interests, 5 AM. J.L. \& MED. 271 (1979); Note, Judicial Limitations on Parental Autonomy in the Medical Treatment of Minors, 59 NEB. L. REv. 1093 (1980).

so See Poe v. Gerstein, 517 F.2d 787, 789 (5th Cir. 1975). The concept of "child as chattel" is a frequently overstated common law principle. Even at common law it was a misdemeanor "to neglect to supply necessaries to a child, being of tender years and unable to provide for itself, and whom the defendant was bound either by duty or contract to support." R. v. Friend, 168 Eng. Rep. 662 (1802). However, it was not sufficient to support an indictment for neglect, abandonment, or exposure to prove "that the children did suffer in some degree . . . but not to any serious extent." R. v. Phillpot, 169 Eng. Rep. 686, 687 (1853). The common law established boundaries to parental decision-making. Clearly outside of the scope of parental choice are decisions which adversely affect the child's opportunity to live. Blackstone commented on the obligations of parents at common law: "By begetting them ... they have entered into a voluntary obligation to endeavor, as far as in them lies, that the life which they have bestowed shall be supported and preserved." 1 W. Blackstone, CommentaRies 447.

${ }^{31}$ See, e.g., Custody of a Minor, 374 Mass. 733, 379 N.E.2d 1053 (1978), aff'd 378 Mass. 732, 393 N.E.2d 836 (1979); In re Cicero, 101 Misc. 2d 699, 421 N.Y.S.2d 965 (Sup. Ct. 1979); 
potential efficacy of the proposed medical treatment, whether there are effective alternative treatments, and the extent of avoidable risk to the child. In particular, a parent's decision to withhold authorization for an established treatment to correct a life threatening medical condition appears to be well outside of the parental "margin of appreciation." 52 It is now well settled that parents are under a duty to prevent avoidable and premature termination of life. Any decision which significantly impedes a child's natural development toward full maturity is outside the established boundaries of parental choice and autonomy. ${ }^{53}$

\section{B. Parental Decisions Which Cause Significant Harm to HANDiCaPPEd ChILDREN}

In theory, courts should approach the question of treatment for handicapped children in the same way as for otherwise healthy children. Unless they can explain clearly why appropriate treatment is not in the child's best interest, they should be expected to adopt a "medical efficacy" standard.

Most courts have been prepared to intervene to preserve the lives of severely handicapped infants in need of beneficial treatment. ${ }^{54}$ However, a

In re Rockowitz, 175 Misc. 948, 25 N.Y.S.2d 624 (Dom. Rel. Ct. 1941) (leg deformity would deteriorate without treatment); In re Sampson, 65 Misc. 2d 658, 317 N.Y.S.2d 641 (Fam. Ct. 1970), aff'd, 37 A.D.2d 668, 323 N.Y.S.2d 253 (1971), aff'd, 29 N.Y.2d 900, 278 N.E.2d 918 , 328 N.Y.S.2d 686 (1972) (court ordered corrective surgery for severe, but not lifethreatening, facial deformity). But see, e.g., In re Green, 448 Pa. 338, 292 A.2d 387 (1972) (remanding to trial court), aff'd on remand, $452 \mathrm{~Pa} .373,307$ A.2d 279 (1973) (juvenile who did not desire surgery to correct spinal curvature was not a neglected child); In re Seiforth, 309 N.Y. 80, 127 N.E.2d 820 (1955) (court would not interfere with parental decision refusing surgery to correct child's harelip and cleft palate).

${ }_{52}$ People v. Labrenz, 411 Ill. 618, 104 N.E.2d 769, cert. denied, 344 U.S. 824 (1952); Luka v. Lowrie, 171 Mich. 122, 136 N.W. 1106 (1912); Raleigh Fitkin-Paul Morgan Mem. Hospital v. Anderson, 42 N.J. 421, 201 A.2d 537, cert. denied, 377 U.S. 985 (1964); State v. Perricone, 37 N.J. 463, 181 A.2d 751, cert. denied, 371 U.S. 890 (1962); Hoener v. Bertinate, 67 N.J. Super. 517, 171 A.2d 140 (1961); In re Vasko, 328 A.D.128, 263 N.Y.S. 552 (1933); In re Brooklyn Hosp., 45 Misc. 2d 914, 258 N.Y.S.2d 621 (Sup. Ct. 1965).

${ }^{53}$ See generally Dickens, infra note 49, at 463; Horwitz, infra note 49; Note, Judicial Limitations on Parental Autonomy in the Medical Treatment of Minors, 59 NEB. L. REv. 1093, 1094 (1980); Note, Birth Defective Infants: A Standard for Non-Treatment Decisions, 30 STAN. L. REv. $599,609,613$ (1978).

${ }^{54}$ In re Cicero, 101 Misc. 2d 699, 421 N.Y.S.2d 965 (Bronx County Sup. Ct. 1979) (appointed guardian to consent to treatment of a myelomeningocele); In re Jeff and Scott Mueller, Nos. 81J3000 and 81J301, slip op. (5th Cir. May 15, 1981) (custody awarded to authorize surgery and medical treatment for separation of Siamese twins jointed at the waist); In re Elin Daniels, No. 81-15577FJ01, slip. op. (Fla. Cir. Ct. June 23, 1981) (court overrode parental refusal to treatment with spina bifida infant); In re B [1981] 1 W.L.R. 1421 (wardship granted in order to treat blocked intestine in Down's Syndrome infant); Superintendent of Family and Child Service and Dawson, 145 D.L.R. (3d) 610 (1983) (interim custody order granted to treat blockage in shunt for six year old boy with severe multiple mental and physical handicaps). See also, Portels, The Elin Daniels Case: An Examination of the Legal and 
few courts have upheld parental non-treatment decisions in circumstances difficult to reconcile with the traditional "best interests" principle. ${ }^{55}$ The Infant Do $e^{56}$ court declined to override a parental decision refusing remedial intestinal surgery for an infant with Down's Syndrome.

In re Phillip B. ${ }^{57}$ involved a Down's Syndrome child, age 11, whose parents refused to consent to heart surgery for a ventricular septal defect. While such surgery is serious, it would be routinely ordered in the case of a normal child. The court refused to grant a guardianship order because the parental decision was "within the range of debatable actions." This decision would follow the established judicial pattern if by "debatable actions" the court meant there was no medical consensus as to the treatment of choice. The facts, however, do not support that interpretation. ${ }^{\mathbf{5 8}}$

Infant Doe and Philip B. are not consistent with existing jurisprudence on parental duties. There is, however, a growing body of well-argued decisions which recognize that intrusive treatment should not be thrust upon an incompetent adult or minor unable to live a viable, recognizable human life.

\section{Where a Child's “Best Interests” are Served by Non-Treatment}

The "best interests" principle, as it pertains to the treatment of handicapped people, requires clarification. This essay is based upon the premise that there may be carefully and narrowly described circumstances in which an infant's handicaps are so grave, and its potential for human experience so limited, that life sustaining treatment is not justified. The standards offered herein may provide a frame of reference for application of the

Ethical Considerations Posed when Parents and Doctors Disagree Whether to Treat a Defective Newborn, 18 Forum 709 (1983).

${ }^{55}$ In Weber v. Stony Brook Hospital, 95 A.D.2d 587, 467 N.Y.S.2d 685 (N.Y. App. Div. 1983), aff'd on procedural grounds, 60 N.Y.2d 208, 456 N.E.2d 1186 (N.Y. Ct. App. 1983) the parents chose a conservative course of treatment with antibiotics instead of surgery for their spina bifida infant. The court held that this was in the child's "best interests," as conservative treatment was "well within accepted medical standards" and the infant's life was not in "imminent danger."

${ }^{56}$ Infant Doe, supra note 5. The court's reasoning in this case cannot be analysed because the judicial record is sealed. See also, Note, Withholding Treatment from Defective Infants: "Infant Doe" Postmortem, 59 Notre Dame L. Rev. 224 (1983).

${ }^{57}$ In re Phillip B., 92 Cal. App. 3d 796, 156 Cal. Rptr. 48 (1979), cert. denied, 445 U.S. 949 (1980).

${ }^{58}$ Despite the risk of mortality, which one cardiologist placed at 3-5 percent and another at 5-10 percent in Philip B., mental retardation texts recommend surgery. Craft, Chromosomal abnormalities, in Tredgold's Mental Retardation 52-53 (M. Craft 12th ed. 1979). The two cardiologists who gave testimony in the Philip B. case both said that the condition was surgically correctable. In this context the risk of mortality due to surgery must be balanced against the certainty of a shortened life if surgery is not performed. See Annas, Denying the Rights of the Retarded: The Phillip Becker Case, 9 Hast. CEN. RPT. 18 (Dec. 1979). 
"best interests" principle: by using a "medical efficacy test" based upon a factual assessment of the benefits, risks, and alternatives to treatment, selective non-treatment decisions would only be made where one of the three narrow criteria proposed above are met. This would ensure that an infant's interest in life would be balanced against its constitutional interest to privacy, including the right to preserve its bodily integrity from intrusive treatment. ${ }^{59}$

Competent adults have always enjoyed the common law right to selfdetermination with regard to medical treatment. ${ }^{60}$ The clear weight of judicial authority supports the right to choose not to receive any life saving or life prolonging treatment. ${ }^{61}$ The U.S. Supreme Court has held that the

${ }^{59}$ In the President's Commission for the Study of Ethical Problems in Medicine and Biomedical and Behavioral Research, Deciding to Forego life-Sustaining Treatment (1983) a "higher value than life is proposed namely personal autonomy. Prolongation of a terminal patient's life imposed over autonomous preference is presented as diminished life, denied dignity." Dickens, The Final Freedom: Deciding to Forgo Life-Sustaining Treatment, 1984 PuB. L. 34, 35.

${ }^{60}$ Under common law, the right of a competent patient to refuse beneficial medical treatment has been judicially stated on many occasions. See, e.g., Justice Cardozo's oft repeated principle in Schloendorff $v$. Society of the New York Hospital, 211 N.Y. 125, 129-30, 105 N.E. 92,93 (1914) ("Every human being of adult years and sound mind has the right to determine what shall be done to his own body . . . .). For a review of the decisions upholding a common law right to self-determination, see Eichner v. Dillon, 73 A.D.2d 431, 455-56, 426 N.Y.S.2d 517, 536-37 (1980). See also In re Conroy, 98 N.J. 321 , 486 A.2d, 1209, 1221 -23 (1985); Perna v. Pirozzi, 92 N.J. 446, 459-65, 457 A.2d 431 (1983); Barber v. Superior Court of State of California, 147 Cal. App. 3d 1006, 195 Cal. Rptr. 484, 489 (1983). The right of selfdetermination which the common law "undoubtedly recognises" is "no more and no less than the right of a patient to determine himself whether he will or will not accept the doctor's medical advice." Sidaway v. Bethlem Royal Hospital Governors [1985] 1 All E.R. 643, 649 H.L., per Lord Scarman.

61 One line of cases suggests that where there is no substantial countervailing interest such as an unborn child or a dependent, an adult patient can refuse a life-saving blood transfusion provided he or she is conscious and understands the implications of the decision. In re Melideo, 88 Misc. 2d 974, 390 N.Y.S.2d 523 (Sup. Ct. 1976); Erickson v. Dilgard, 44 Misc. 2d 27, 252 N.Y.S.2d 705 (Sup. Ct. 1962); Annot. 93 A.L.R. 3d 67, 72 (1979).

Specifically, if the refusal of a blood transfusion was based upon religious beliefs, the court would uphold the patient's decision, e.g., In re Osborne, 294 A.2d 372 (D.C. Cir., 1972); In re Estate of Brooks, 32 Ill.2d 361, 205 N.E.2d 435 (1965), but not if the patient was incompetent and emergency treatment was needed to save his or her life, see, e.g., Application of President \& Directors of Georgetown College, Inc., 331 F.2d 1000 (D.C. Cir.), reh'g den., 331 F.2d 1010 (D.C. Cir.), cert. denied, 377 U.S. 978 (1964); John F. Kennedy Memorial Hospital v. Heston, 58 N.J. 576, 279 A.2d 670 (1971), or if the patient were a minor or had a dependent, see, e.g., Application of President and Directors of Georgetown College, Inc., 331 F.2d at 1007-08, or pregnant, Raleigh Fitkin-Paul Morgan Memorial Hospital v. Anderson, 42 N.J. 421, 201 A.2d 537, cert. denied, 377 U.S. 985 (1964).

Competency of the patient to refuse life-saving treatment has also been the major factor influencing courts in other contexts. In Lane v. Candura, 6 Mass. App. Ct. 377, 376 N.E.2d 1232 (1978), in In re Quackenbush, 156 N.J. Super. 282, 383 A.2d 785 (1978) and Petition of Nemser, 51 Misc. 2d 616, 273 N.Y.S.2d 624 (1966), courts would not allow applications to override the refusal of a patient to consent to the amputation of a gangrenous leg because of insufficient evidence of their incompetence. Similar facts were present in State Dep't of Human Service v. Northern, 563 S.W.2d 197 (Tenn. Ct. App. 1978), appeal dismissed as moot, 
right to privacy is broad enough to encompass the "freedom to care for one's health and person," 62 and most courts have relied on this constitutional principle in their decisions on life sustaining treatment. ${ }^{63}$ This right, however, is not absolute. The courts may intervene where an individual's right to privacy conflicts with a recognized State interest. ${ }^{64}$ The patient's

436 U.S. 923 (1978), but in that case the court held the patient was competent and the refusal of an amputation could be overridden. In re Yetter, $62 \mathrm{~Pa}$. D. \& C.2d 619 (1973), the court refused to appoint a guardian for the purpose of consenting to medical treatment for breast cancer on evidence that the patient was competent and had no children. There are a large number of cases where courts have supported substitute decisions to remove life support systems from dying patients; all save two, Satz v. Perlmutter, 362 So. 2d 160 (Fla. Dist. Ct. App. 1978), aff' $d$, 379 So. 2d 357 (Fla. 1980), and Bartling \& Bartling v. Superior Court, 85 Daily J. D.A.R. 83 (Cal. 1985), involved comatose or other clearly incompetent patients and are not dealt with in note 66 , infra. Similarly, courts have been prepared to honor the rational decision of a competent patient not to undergo life-prolonging treatment such as renal dialysis even though he has since become comatose. In re Lydia E. Hall, Hosp., 116 Misc. 2d 477, 455 N.Y.S.2d 706 (Sup. Ct. 1982). See generally Annot., 93 A.L.R. 3d 67 (1979); Byrn, Compulsory Lifesaving Treatment for the Competent Adult, 44 Fordham L. Rev. 1 (1975); Cantor, A Patient's Decision to Decline Life Saving Medical Treatment: Bodily Integrity Versus the Preservation of Life, 26 Rutgers L. Rev. 228 (1973); Kennedy, The Legal Effect of Requests by the Terminally Ill and Aged Not to Receive Further Treatment From Doctors, 1976 CRIM. L. Rev. 217; Montange, Informed Consent and the Dying Patient, 83 YALE L.J. 1632 (1974); Note, Voluntary Active Euthanasia for the Terminally Ill and the Constitutional Right to Privacy, 69 CoRnell L. Rev. 363, 369-79.

${ }^{62}$ Doe v. Bolton 410 U.S. 179, 213 (1973) (Douglas, J., concurring). See also, Roe v. Wade, 410 U.S. 113 (1973) (a woman's right to decide whether to terminate her pregnancy was conditionally protected under the rubric of privacy); see supra note 2.

${ }^{63}$ Severns v. Wilmington Med. Center, Inc., 421 A.2d 1334 (Del. 1980); Satz v. Perlmutter, 362 So. 2d 160 (Fla. Dist. Ct. App. 1978), aff'd, 379 So. 2d 359 (Fla. 1980); Lane v. Candura, 6 Mass. App. Ct. 377, 376 N.E.2d 1232 (1978); In re Quackenbush, 156 N.J. Super. 282, 383 A.2d 785 (1978); Belchertown v. Saikewicz, 373 Mass. 728, 370 N.E.2d 417 (1977); Suenram v. Society of Valley Hospital, 155 N.J. Super. 593, 383 A.2d 143 (1977); In re Quinlan, 70 N.J. 10, 355 A.2d 647 (1976); In re Yetter, 62 Pa. D. \& C.2d 619 (1973). Other courts have taken the view that, while a right of privacy may apply to cases where patients refuse life-sustaining treatment, it is not necessary so to decide since the right is embraced within the common law principle of self-determination. See, e.g., In re Conroy, 98 N.J. 321, 348, 486 A.2d 1209, 1223 (Sup. Ct. 1985), In re Storar, 52 N.Y.2d 363, 376-77, 420 N.E.2d 64, 78, 438 N.Y.S.2d 266, 272-73, cert. denied, 454 U.S. 58 (1981).

${ }^{64}$ Several courts have identified various state interests in requiring life-sustaining treatment to be given against the wishes of dying patients. In re Conroy, 98 N.J. 321, 348-55, 486 A.2d 1209, 1223-26 (1985); In re Colyer, 99 Wash.2d 114, 122, 660 P.2d 738, 743 (1983); Saltz v. Perlmutter, 362 So. 2d 160, 162 (Fla. Dist. App. 1978); In re Spring, 380 Mass. 629, 640, 405 N.E.2d 115, 123 (1980); Commissioner of Correction v. Myers, 379 Mass. 255, 261, 399 N.E.2d 452, 456 (1970); Superintendent of Belchertown State School v. Saikewicz, 373 Mass. 728, 370 N.E.2d 417 (Sup. Ct. 1977); In re Torres, 357 N.W.2d 332, 339 (Minn. 1984); Bartling v. Superior Court, 163 Cal. App. 3d 186, 209 Cal. Rptr. 220 (1984). These state interests include:

(i) The preservation of life, which is generally considered the most important of the state interests. This interest is weakest where a competent patient refuses life-sustaining treatment and where prolongation of life is temporary and artificial. Therefore, it will "usually not foreclose a competent person from declining life-sustaining medical treatment for himself." In $r e$ Conroy, $98 \mathrm{~N}$.J. at $349,486 \mathrm{~A} .2 \mathrm{~d}$ at 1223 . It would be a different matter if some other actual or potential life were at stake which could not adequately protect itself. See, e.g., State v. Pericone, 37 N.J. 463, 181 A.2d 751, cert. denied, 371 U.S. 890 (1962); Muhlenberg Hospital v. 
right to self-determination may also be eclipsed by the interests of parties other than the patient, e.g., those of a near-term fetus or a dependent child ${ }^{65}$ Nevertheless, absent a substantial competing interest, the competent patient has the choice to refuse life-sustaining treatment.

Although infants cannot express their own wishes, their interests should, nonetheless, be measured in the same manner as those of an incompetent adult. The fact that incompetent adults cannot determine where their interests lie has not prevented courts from extending to them the right to refuse treatment. ${ }^{66}$ The threshhold decisions concern how the

Patterson, 128 N.J. Super. 498, 320 A.2d 518 (Law. Div. 1974) (both, in effect, requiring blood transfusion to save infant's life over parents' refusal to consent).

(ii) The prevention of suicide. See Application of the President \& Directors of Georgetown College, Inc., 331 F.2d 1000, reh'g denied, 331 F.2d 1010, cert. denied, 377 U.S. 978 (1964); John F. Kennedy Memorial Hospital v. Heston, 58 N.J. 576, 279 A.2d 670 (1971); State v. Perricone, 37 N.J. 463, 181 A.2d 751, cert. denied, 371 U.S. 890 (1962). The state interest in the prevention of suicide is least significant where the patient retains a basic wish to live and where the affliction is not self-induced. See Erickson v. Dilgard, 44 Misc. 2d 27, 252 N.Y.S. 705 (Sup. Ct. 1962).

(iii) The maintenance of the ethical integrity of the medical profession. See Application of the President \& Directors of Georgetown College, Inc., 331 F.2d 1010, reh. denied, 331 F.2d 1010 , cert. denied, 377 U.S. 978 (1964); 58 N.J. 576,279 A.2d 670 (1971). The force of this interest is lessened by the prevailing medical ethical standards, which do not invariably demand that all efforts toward life prolongation be made. See Bryn, Compulsory Lifesaving Treatment for the Competent Adult, 44 Fordham L. Rev. 1 (1975). Further the individual right to self-determination usually outweighs institutional considerations.

${ }^{65}$ A state interest of some potential magnitude is the protection of third parties, particularly minor children, from harm resulting from the decision of a competent adult to refuse life saving or life-prolonging treatment. See, e.g., Application of the President \& Directors of Georgetown College, Inc., 331 F.2d 1000, reh. denied, 331 F.2d 1010, cert. denied, 377 U.S. 978 (1964); Holmes v. Silver Cross Hosp. of Joliet, Ill., 340 F. Supp. 125 (D. Ill. 1972); Hamilton v. McAuliffe, 277 Md. 336, 353 A.2d 634 (1976); United States v. George, 239 F. Supp. 752 (D.C. Conn. 1965). This interest is insignificant where the patient's family are all adults and are all in agreement with his wishes. See, e.g., Saltz v. Perlmutter, 362 So. 2d 160 (Fla. Dist. Ct. App. 1978), aff'd, 379 So. 2d 359 (Fla. 1980); Superintendent of Belchertown State School v. Saikewicz, 373 Mass. 728, 370 N.E.2d 417 (1977). See also, Annot. 93 A.L.R. 3d 67, 82-83 (1979). The interest of minors has often been overstated, for in cases of life-prolonging rather than life-saving treatment, the minor would not benefit from the slow anguished death of a parent as opposed to a quicker natural death. Other "third party" interests which have been upheld include compulsory treatment for the protection of public health, see, e.g., Jacobson v. Mass., 197 U.S. 11 (1905) (compulsory smallpox vaccination) and to prevent serious risk to prison security, see, e.g., Commissioner of Correction v. Myers, 379 Mass. 255, 263, 265, 399 N.E.2d 452, 457, 458 (prisoner must submit to kidney dialysis rather than be transferred to a lower security prison). Accord, In re Caulk, 125 N.H. 226, 480 A.2d 93 (1984).

${ }^{66}$ There is now substantial judicial support for the proposition that the rights to selfdetermination and/or to privacy, sometimes resulting in the withholding of life-sustaining treatment, extends to incompetent patients. The main areas of support can be found in two lines of cases. The first flows from Superintendent of Belchertown State School v. Saikewicz, 373 Mass. 728,370 N.E.2d 417 (1977). The Saikewicz court asked whether there should be any social and judicial choice not to administer life-prolonging treatment to an incompetent person. The court answered in the affirmative based upon the "principles of equality and respect for all individuals." Recognition of the right to refuse treatment "must extend to the 
incompetent individual's interests are to be assessed, and who should be entrusted with making those judgments on the ward's behalf. Courts have formulated various standards ${ }^{67}$ and procedures ${ }^{68}$ for making substitute

case of an incompetent, as well as a competent, patient because the value of human dignity extends to both. The court concluded that the interests of an incompetent person are "not necessarily served by imposing on such persons results not mandated as to competent persons similarly situated," because it would treat the ward as a person of "lesser status or dignity." 373 Mass. at 746, 370 N.E.2d at 427-28. Courts have consistently followed this part of the reasoning in Saikewicz. See, e.g., In re Conroy, 98 N.J. 321,486 A.2d 1209, 1229 (1985); In re Spring, 380 Mass. 629, 405 N.E.2d 115 (1980).

The second line of cases are those following the decision of the New Jersey Supreme Court in In re Quinlan, 70 N.J. 10,.355 A.2d 647, cert. denied, 429 U.S. 922 (1976). Karen Quinlan was in an irreversible coma and was being kept alive through the use of life support systems. She had virtually no choice of returning to a "cognitive sapient life." 70 N.J. at $26,355 \mathrm{~A} .2 \mathrm{~d}$ at 655 . All the courts which have followed Quinlan have agreed that the extremely poor prognosis and the high degree of bodily invasion involved in sustaining the life of a permanently comatose patient meant her right of privacy outweighed the state's interest in preserving her life. Courts have, however, insisted on varying procedures to effectuate the right to privacy. See, e.g., In re Hamlin, 102 Wash.2d 810, 689 P.2d 738 (1983); Barber v. Superior Court, 147 Cal. App. 3d 1006, 1022, 195 Cal. Rptr. 484, 493 (1983); John F. Kennedy Memorial Hospital, Inc. v. Bludworth, 452 So. 2d 921 (Fla. 1984); In re Torres, 357 N.W.2d 332 (Minn. 1984); Leach v. Akron Gen. Med. Center, 68 Ohio Misc. 1, 426 N.E.2d 809 (1980); Severns v. Wilmington Med. Center, 421 A.2d 1334 (Del. 1980); Eichner v. Dillon, 73 A.D.2d 431, 426 N.Y.S.2d 517 (1980), aff'd sub nom., In re Storar, 52 N.Y.2d 363, 420 N.E.2d 64 (1981). In re Lydia E. Hall Hosp., 116 Misc. 2d 477, 455 N.Y.S.2d 706 (Sup. Ct. 1982), was not wholly on point because the patient herself, while still competent, expressly stated her wish to be removed from kidney dialysis when she slipped into a coma. Courts have even been prepared to rule that treatment of a terminally ill incompetent patient is not necessary before the fact. A "no code" or "do not resuscitate" (DNR) order, entered in the medical record of a terminally ill incompetent patient, directs the hospital staff not to apply intrusive resuscitative measures in the event of cardiac or respiratory failure. Such orders have been upheld by the courts. See, e.g., Custody of a Minor, 385 Mass. 697, 434 N.E.2d 601 (1982); In re Dinnerstein, 6 Mass. App. 466, 380 N.E.2d 134 (1978).

${ }^{67}$ Compare In re Conroy, 98 N.J. 321,486 A.2d 1209 (1985) (laying down three separate standards: Subjective ("substitute judgment") test-where it is clear the particular patient would have refused the treatment in the circumstances; limited objective test-treatment can be terminated for a nursing home resident with severe and permanent mental impairments and limited life expectancy where patient has not unequivocally expressed his desires before becoming incompetent and it is clear treatment would merely prolong suffering; pure objective ("best interests") test-in the absence of any trustworthy evidence of patient's views, treatment can be withheld from nursing home resident of above description when burdens of life markedly outweigh benefits so that recurring, unavoidable, and severe pain of life with the treatment would be inhumane) with Barber v. Superior Court, 147 Cal. App. 3d 1006, 1021, 195 Cal. Rptr. 484, 493 (1983) (adopting relevant factors set out by President's Commission for the Study of Ethical Problems in Medicine and Biomedical and Behavioral ReSearch, Deciding to Forego Life-Sustaining Treatment 134-35 (1983): relief of suffering, the preservation or restoration of functioning, the quality as well as the extent of the life sustained, and the impact on those closest to the patient). See In re Conroy, 98 N.J. 321, 396-98, 486 A.2d 1244, 1248-50 (1985) (Handler, J., dissenting in part).

${ }^{68}$ Courts considered the issue of withdrawal of life-sustaining treatment have used different procedures to exercise the incompetent's right to privacy. The New Jersey Supreme Court, for example, has allowed the patient's guardian to make the decision in certain circumstances. In re Quinlan, 70 N.J. 10, 355 A.2d 647, cert. denied, 429 U.S. 922 (1976) (guardian can make decision when patient is irreversibly comatose and family, attending 
judgments, but none have entirely precluded the notion that the interests of the ward may in some circumstances best be served by withholding treatment. "Living will" statutes, which allow a person to indicate his or her preference for treatment in the event of becoming incompetent, are consistent with the judicially established principle that incompetent patients retain their right to privacy. ${ }^{69}$ Children also retain a right to substitute judgments and, at times, non-treatment may best serve their interests. ${ }^{70}$ The determining legal and moral factors should include the severity of the handicap, the hopelessness of the prognosis, and the intrusiveness of the treatment. It should not, however, consider the patient's chronological age.

In cases concerning handicapped children, courts have been reluctant to countenance parental decisions which would result in the child's early

physician and hospital prognosis committee concur); In re Conroy, 98 N.J. at 375, 383-85, 486 A.2d at 1237, 1241-42 (1985) (concurrence of above parties not entirely appropriate in cases of incompetent nursing home resident who is not permanently comatose; interested person such as guardian, close family member, attending physician of nursing home to notify Office of Ombudsman; evidence of patient's condition to be furnished by attending physician and nurses, and two independent physicians to confirm medical condition and prognosis; if the two physicians supply necessary medical foundation, guardian, with concurrence of attending physician, may withhold treatment if he believes in good faith that one of the appropriate tests is satisfied; ombudsman must concur in decision; if limited or pure objective test used, family or next of kin must also concur).

The Massachusetts Supreme Court, on the whole, has preferred prior judicial review of cases where life sustaining treatment is to be withdrawn from an incompetent patient. Superintendent of Belchertown State School v. Saikewicz, 373 Mass. 728, 370 N.E. 2d 417 (1977). That court had to make clear in In re Dinnerstein, 6 Mass. App. Ct. 466, 380 N.E.2d 134 (1978) that a court order was not required before a physician could insert a "do not resuscitate" order into a patient's record. But where there were no family members willing to make a decision in concurrence with medical staff for a "DNR" order, judicial review was held to be appropriate. Custody of a Minor, 385 Mass. 697, 434 N.E.2d 601 (1982).

The Washington Supreme Court instituted the following procedure for determining whether to terminate life-sustaining treatment for an incompetent patient who has no available family: general guardian must be appointed; if treating physicians and prognosis committee are unanimous and guardian concurs, medical approval is not required; conflicts within or between the hospital, prognosis committee, attending physicians, or guardian should be determined by trial court. In re Hamlin, 102 Wash.2d 810, 689 P.2d 1372 (1984), modifying In re Colyer, 99 Wash.2d 114, 660 P.2d 738 (1983). The different procedures in Quinlan, Saikewicz, and Colyer are discussed in Note, The Incompetent's Right to Refuse Treatment, 51 TENN. L. REv. 145 (1983).

${ }^{69}$ A number of legislatures have recognized the validity of "living wills." See, e.g., CAL. Health \& SafeTy Code 887185-95 (West Supp. 1985). The National Conference of Commissioners on Uniform State Laws has submitted a proposal for a uniform act recognizing the enforceability of "living wills" in certain circumstances. Whether or not they are legally binding, such wills are relevant evidence of a patient's intent. John F. Kennedy Memorial Hospital, Inc. v. Bludworth, 452 So. 2d 921,926 (Fla. 1984).

${ }^{70}$ See, e.g., In re Guardianship of Barry, 445 So. 2d 365 (Fla. Dist. Ct. App. 1984) (constitutional right to privacy of a ten-month-old terminally ill child wholly lacking in cognitive brain functioning and completely unaware of his surroundings could be exercised by his legal guardians by discontinuing life support system). The Florida Supreme Court specifically supported this analysis in John F. Kennedy Memorial Hospital, Inc. v. Bludworth, 452 So. 2d 921,926 (1984). 
death without treatment. ${ }^{71}$ Nevertheless, even those courts with vitalist preconceptions have not foreclosed the possibility that a minor's interests may best be served by non-treatment. The English Court of Appeal asked "whether the life of the child is demonstrably going to be so awful that in effect the child must be condemned to die ..."72 In opting for treatment in the particular case of a Down's Syndrome infant with an intestinal blockage, Lord Templeman said: "There may be cases . . of severe proved damage where the future is so certain and where the life of the child is bound to be so full of pain and suffering that the court might be driven to a different conclusion."73

The Court in In re Cicero, ${ }^{74}$ while noting that surgery for a spina bifida infant would give the child "a reasonable chance to live a useful, fulfilled life," left open the possibility of a different decision when confronted with "a 'hopeless' life." Custody of a Minor ${ }^{75}$ presented such a "hopeless life," an infant suffering from cyanotic heart disease which at the time was incorrectable. In this case, the Massachusetts Supreme Judicial Court upheld a juvenile court order that "if cardiac and/or respiratory onset occurs, no heroic life saving treatment should be administered."76 The court analogized to the case of an incompetent terminally ill adult; this would raise "the issue of whether and by what means a person has the right to refuse the invasion of his or her bodily integrity by refusing extraordinary medical treatment."77 The court based its decision on narrow facts: an incurable illness, intrusive treatment, and the potential for "agony and suffering."

\section{LEGISLATIVE AND ADMINISTRATIVE CONTROL OVER SELECTIVE NON-TREATMENT DECISIONS}

On May 15, 1985, new regulations were enacted to guide the treatment and care of handicapped infants. These regulations implemented the Child

${ }^{1}$ See supra, note 51-53.

${ }^{72}$ In $r e$ B. [1981] 1 W.L.R. 1421, 1424. This passage was quoted with approval in the Canadian case of Superintendent of Family and Child Services v. R.D., supra note 53, at 623. The Canadian case involved a six year old severely mentally retarded boy with no control over his faculties, limbs or bodily functions. His parents refused consent to surgery necessary to correct a blockage in a shunt. The court said "[t]here looms the awful possibility that without the shunt the child will endure in a state of progressing disability and pain. It is too simplistic to say that the child should be allowed to die in peace." The court granted an interim custody order to ensure treatment, but left open the possibility of a different conclusion in cases of terminally ill children whose lives are "imponderable." See Sneideman, The Stephen Dawson Case: Whose Decision is it Anyway? 14 MaN. L.J. 165 (1984).

${ }^{73}$ In re B. [1981], 1 W.L.R. $1421,1424$.

${ }^{74} 101$ Misc. 2d 699, 421 N.Y.S.2d 965, 968 (Bronx County Sup. Ct. 1979).

75385 Mass. 697, 434 N.E.2d 601 (1982).

${ }^{76} \mathrm{Id}$. at 712,434 N.E.2d at 609.

${ }^{77}$ Id. at 708, 434 N.E.2d at 607. 
Abuse Amendments of 1984. This section contains a brief examination of previous attempts to regulate treatment decisions relating to handicapped infants pursuant to Section 504 of the Rehabilitation Act of 1973. An analysis of the new regulations follows, comparing them with the standard previously proposed.

\section{A. HHS Rules Based Upon Section 504 of the Rehabilitation Act of 1973}

On April 12, 1982, the court in In re Infant Doe ${ }^{78}$ chose not to intercede in a parental decision to withhold surgery, food, and water from a Down's Syndrome infant born with a tracheo-oesophageal fistula. ${ }^{79}$ This condition prevents food from reaching the stomach and usually calls for corrective, albeit serious, surgery for an otherwise physically and mentally healthy child. The infant died six days after birth.

The Infant Doe case spurred governmental response. On April 30, 1982 President Reagan sent a memorandum instruction to the Secretary of Health and Human Services ("HHS") directing the Secretary to notify health care providers that Section 504 of the Rehabilitation Act of $1973^{80}$ applies to the treatment of handicapped infants. ${ }^{81}$ This section prohibits discrimination against handicapped persons by federal fund recipients. The HHS Director of the Office of Civil Rights issued the notice on May 18, $1982 .^{82}$

${ }^{78}$ Infant Doe, supra note 5.

${ }^{79}$ See supra note 6.

${ }^{80}$ Section 504 provides that "[n]o otherwise qualified handicapped individual in the United States ... shall, solely by reason of his handicap, be excluded from the participation in, be denied the benefits of, or be subjected to discrimination under any program or activity receiving Federal financial assistance ...."29 U.S.C. $§ 794$ (1982).

${ }^{81}$ The legislative history of the Child Abuse Amendments of 1984 cites the Infant Doe case as giving rise to the President's memorandum to the Attorney General (who was ordered to report on the constitutional and statutory remedies available to prevent withholding of medical treatment from handicapped persons). It also cites the decision to withhold treatment from siamese twins who were born handicapped in Danville, Illinois which resulted in a custody battle and filing of criminal charges against the parents and attending physicians. Legislative History, supra note 9, at 2922-23.

${ }^{82}$ Discrimination Against the Handicapped by Withholding Treatment or Nourishment: Notice of Health Care Providers, 47 FED. REg. 26,027 (1982) (applying 45 C.F.R. § 84 to health services for handicapped children). The notice states that:

It is unlawful ... to withhold from a handicapped infant nutritional sustenance or medical or surgical treatment required to correct a life threatening condition if (1) the withholding is based on the fact that the infant is handicapped; and (2) the handicap does not render the treatment or nutritional sustenance medically contraindicated.

The notice also recognized that Federal fund recipients did not have total control over treatment, but suggested parental withholding of consent for treatment should not be aided by allowing the infant to remain in the institution; failure to comply with $\$ 504$ subjected recipients "to possible termination of federal assistance." 
On March 7, 1983, the Secretary of HHS promulgated an interim final regulation under Section 504. Among other things, this required federally assisted health care institutions to display conspicuous notices advising that federal law prohibits discriminatory failure to feed and provide care for handicapped infants. ${ }^{83}$ The District Court for the District of Columbia invalidated the regulation in American Academy of Pediatrics $v$. Heckler. ${ }^{84}$ Judge Gesell concluded that the interim final regulation constituted an arbitrary and capricious agency action. ${ }^{85}$ Furthermore, the court found that the Secretary had failed to follow procedural requirements in its promulgation. ${ }^{86}$

Despite Judge Gesell's ruling, HHS issued a new "proposed rule" on July 5, 1983 which essentially restated the initial rule. ${ }^{87}$ After reviewing and analyzing comments on the proposed rule, the HHS issued its "final rule" on January $12,1984 .^{88}$ These regulations were set aside in American Hospital

${ }^{* 3}$ Non-Discrimination on the Basis of Handicaps, 48 FEv. REG. 9630 (1983) (modifying 45 C.F.R. $\$ 84.61$ ). The notice advised any person having knowledge of proscribed discrimination to contact a toll free HHS "hotline" or the child protection agency. The regulation also authorized HHS to conduct immediate investigation to protect the health or life or handicapped infants.

${ }^{84} 561$ F. Supp. 395 (D.D.C. 1983).

${ }^{85}$ See Administrative Procedure Act, 5 U.S.C. $\$ 706$ (2)(A); which extends the scope of judicial review to holding unlawful and setting aside agency action which is "arbitrary or capricious." Judge Gesell said the record reflected no consideration of: the disruptive effects a 24 hour "hotline" upon the treatment of newborns; the effects of forced removal of an infant from hospital if the parent refuses to consent to treatment; whether termination of painful intrusive treatment might be appropriate where the infant's clear prognosis is death within a few days or months. Academy of Pediatrics, 561 F. Supp. at 399-400.

${ }^{86}$ The court found that the rule was not issued in accordance with either the public notice or 30 day delay-of-effective date requirements of the Administrative Procedure Act, 5 U.S.C. $\$ 553$ (b) \& (d); the Secretary also failed to demonstrate good cause why the Administrative Procedure Act notice procedures should be waived. Academy of Pediatrics, 561 F. Supp. at 400-01.

${ }^{87}$ Non-discrimination on the Basis of Handicap Relation to Health Care for Handicapped Infants, Proposed Rule, 48 FED. REG. 30,846 (July 5, 1983) (proposed rules modifying 45 C.F.R. 84.61).

${ }^{88}$ Non-Discrimination on the Basis of Handicap in Programs and Activities Receiving or Benefitting from Federal Financial Assistance: Procedures and Guidelines Relating to Health Care for Handicapped Infants, Final Rule, 49 FED. REc. 1622, 45 C.F.R. 84.55 (1984). These provided, inter alia, as follows: (a) Infant Care Review Committee (ICRC) in recipient health care institutions were encouraged but not mandated; (b) Posting of informational notice where health care professionals, but not necessarily parents, could see it. The notice drew attention to proscribed discrimination under Section 504 whereby nourishment and medically beneficial treatment are withheld solely on grounds of infant's present or anticipated impairments, and gave telephone numbers of hospital contact (where there was one), appropriate child protection agency and a 24 hour "hotline" at HHS; (c) Responsibilities of Recipient State Child Protection Agency to use full authority to prevent instances of unlawful neglect including, where appropriate, on-site investigation of such reports and timely applications for court orders for lifesustaining treatment; (d) Expedited Access to Records which was not limited to business hours when necessary to protect life or heath of a handicapped individual. 
Association v. Heckler ${ }^{89}$ because they were promulgated without statutory authority pursuant to the Administrative Procedure Act. ${ }^{90}$ The American Hospital Association decision was directly controlled by United States v. University Hospital, State University of New York. ${ }^{91}$ In that case, "Baby Jane Doe" was born with multiple birth defects including spina bifida, ${ }^{92}$ microcephaly ${ }^{93}$ and hydrocephalus. ${ }^{94}$ Dual corrective surgical procedures were refused by the parents, and HHS sought access to the infant's medical records to determine whether this was a "legitimate medical judgment rather than based solely on a handicapping condition." 95 HHS based its authority to conduct an investigation on Section 504. The Court of Appeals found that Section 504, ${ }^{96}$ prohibiting "discrimination"97 against "otherwise qualified"98 handicapped people, did not reach medical decisions involving handicapped infants. Thus HHS lacked statutory authority to conduct an investigation or to compel production of the medical records of Infant Doe. $^{99}$

\section{B. Child Abuse Amendments of 1984 and Implementing Regulations}

The Child Abuse Prevention and Treatment Act, originally enacted in 1974, was the first federal legislation focusing on child abuse and ne-

89 No. 84-6211 (2d Cir. Dec. 27, 1984) cert. granted, 105 S.Ct. 3475 (1985).

${ }^{90}$ U.S.C. $\$ 706(2)(C)(1971)$ (which extends scope of judicial review to set aside agency action which is in excess of statutory authority).

91729 F.2d 144 (2d Cir. 1984).

92 See supra note 45.

${ }^{93}$ Microcephaly is an abnormal smallness of the head in relation to the rest of the body: a congenital condition in which the brain is not fully developed. Concise Oxford Medical Dictionary 392-93 (Corgi ed. 1982).

${ }^{94}$ Hydrocephalus is an abnormal increase in the amount of cerebrospinal fluid within the ventricles of the brain causing an enlarged head in infants. Id. at 298. Spina bifida is commonly associated with hydrocephalus.

95 United States v. University Hospital, State University of New York, 729 F.2d at 157.

96 See supra note 80 for the text of Section 504.

97 "Where the handicapping condition is related to the condition(s) to be treated, it. will rarely, if ever, be possible to say with certainty that a particular decision was 'discriminatory,", United States v. University Hospital, State University of New York, 729 F.2d at 157.

${ }^{98}$ Doe v. New York University, 666 F.2d 761 (2d Cir. 1981), establishes that $\S 504$ prohibits discrimination only where the handicap is unrelated to the services in question. "[W]here medical treatment is at issue, it is typically the handicap itself that gives rise to, or at least contributes to, the need for services." United States v. University Hospital, State University of New York, 729 F.2d at 156.

${ }^{49}$ HHS has consistently defended its right to promulgate regulations pursuant to Section 504 and will, if the prior final regulation is reinstated in subsequent stages of ongoing litigation, consider any revisions necessary to facilitate coordinated action with the regulations recently promulgated under the 1984 Amendments to the Child Abuse and Neglect Prevention and Treatment Act of 1974. See Child Abuse Rules, supra note 7. See also infra notes 101-129 and accompanying text. Section 127(a) of the Child Abuse Amendments of 1984, Pub.L. 98 Stat. 1749,1754 , (1984) states that no provision of the 1984 Act is intended to effect any right or protection under Section 504 of the Rehabilitation Act of 1973 and Congress has established a "policy of neutrality" on this legal controversy concerning the applicability of Section 504 to health care for handicapped infants. See 130 CoNG. Rec. S-12392, daily ed. (Sept. 28, 1984) (Letter from Senators Hatch, Denton, Nickles, Kassebaum, Dodd and Cranston). 
glect. ${ }^{100}$ The Child Abuse Amendments of 1984 extended the Act to cover the withholding of medically indicated treatment from handicapped infants. ${ }^{101}$ The Amendments were a "substantial consensus" achieved between the principal congressional sponsors and a diverse coalition of medical, pro-life, and disability organizations. ${ }^{102}$ Section 124 of the Act requires the Secretary of HHS to publish proposed and final regulations implementing the statutory requirements for responding to medical neglect. The Secretary is also required to publish interim and final model guidelines to encourage Infant Care Review Committees.

On December 10, 1984, HHS published a Notice of Proposed Rulemaking (NPRM) ${ }^{103}$ which included a "cookbook" of binding definitions of the statutory phrase "withholding medically indicated treatment." HHS received more than 116,000 letters in response to the NPRM. Medical associations, whose support had been essential in achieving the legislative compromise, argued that the "impossible catalogue of binding definitions" upset the statute's careful balance. ${ }^{104}$ In a letter to HHS, the principal sponsors of the Act noted that each statutory definition "was chosen with utmost care" and asked for "every consideration" to ensure that the careful balance of the statute would not be disturbed. ${ }^{105}$ In the final Child Abuse Rules, published April 15, 1985, HHS deleted all clarifying definitions except the two that appeared in the Conference Committee Report. ${ }^{106}$ Instead, the Appendix to the Final Rules contains non-binding "interpretive guidelines" which represent HHS's interpretation of the statutory language.

The Act of 1984 and implementing regulations have four main provisions, which are summarized below.

\section{New Basic State Grant Requirement}

Section $4(b)(2)(k)^{107}$ mandates, as a condition to receiving State grant funds under the Act, that participating State Child Protective Services agencies establish procedures for reporting medical neglect, including in-

\footnotetext{
${ }^{100}$ Pub. L. No. 93-247, 88 Stat. 4 (1974) (codified or amended at 42 U.S.C. § 5101) (1983 \& Supp. 1985) [hereinafter cited as the Child Abuse Prevention and Treatment Act of 1974].

${ }^{101}$ Child Abuse Amendments of 1984, supra note 7.

${ }^{112}$ Child Abuse Proposed Rules, supra note 20, at 2.

${ }^{103} I d$. at 48,160 .

${ }^{104}$ Child Abuse Rules, supra note 7.

105 Id. at 14,879 .

${ }^{106}$ The two definitions are of the terms "infant" and "reasonable medical judgment." See infra notes $117 \& 120$.

${ }_{107}$ The effective date of this section is October 9, 1985; funds have been appropriated under Section 4(C) so the waiver provision is not in effect. Child Abuse and Prevention Act of 1974, 42 U.S.C. $\$ 5103$ (b)(2)(K), amended by the Child Abuse Amendments of 1984, Pub. L. No. $98-457,98$ Stat. $1749 \S 128$ (b)(1)(2).
} 
stances of withholding of medically indicated treatment from disabled infants with life threatening conditions. These procedures must provide for: coordination and consultation with individuals designated by, and within, appropriate health care facilities; prompt notification of cases of suspected medical neglect by individuals designated within these facilities; ${ }^{108}$ and authority under state law for the child protection service system to pursue legal, including judicial, ${ }^{109}$ remedies to prevent the withholding of medically indicated treatment from disabled infants with life threatening conditions. ${ }^{110}$

Furthermore, state reporting procedures must comply with pertinent existing requirements for State Child Protective Services set out in the Child Abuse Prevention and Treatment Act and Regulations. ${ }^{111}$ In particular, the Child Protective Services agency must have procedures to obtain, in a manner consistent with state law, medical records necessary for the investigation of reported medical neglect. A court order or other method for obtaining an independent medical examination of the infant must also be available when necessary to resolve a report of medical neglect. ${ }^{112}$

The most important feature of the new basic state grant requirement is its incorporation of existing child abuse and neglect reporting and investigation requirements to cases of withholding medically indicated treatment from disabled infants. The Child Abuse provisions are neither as specific nor as intrusive as those requiring "conspicuous notices," reporting "hotlines," and "investigation squads" contained in various stages of the Section 504-based regulations. ${ }^{113}$ They also materially differ from the

${ }^{108}$ The programs and/or procedures must specify that the child protective services will promptly contact each health care facility to obtain the name, title and telephone number of individuals designated by such facilities for the purposes of coordination, consultation and notification activities, and will at least annually recontact each facility to obtain any changes in the designations. Child Abuse Rules, supra note 7, (to be codified at 45 C.F.R. $\$ 1340.15$ (c)(3)).

${ }^{109}$ In every case which results in a judicial proceeding, the state must ensure the appointment of a guardian ad litem to represent and protect the rights and best interests of the infant. Child Abuse Rules, supra note 7 (to be codified at 45 C.F.R. $\$ 1340.14$ (́g)).

${ }^{110}$ Child Abuse Rules, supra note 7 (to be codified at 45 C.F.R. $\left.\$ 1340.15(c)(1)(2)\right)$. Specific statutory reference to the authority to institute legal proceedings is made in the Act only because of the uncertainties of particular child protective agencies to take such action in cases involving withholding of medically indicated treatment from disabled infants. Legislative History, supra note 9, at 2971.

11. Child Abuse Rules, supra note 7 (to be codified at 45 C.F.R. $\$ 1340.15(c)(4)$ ). The provision for reporting and investigating child abuse are set out in the Child Abuse Rules supra note 7 (to be codified at 45 C.F.R. $\$ 1340.14$ (c) and (d)), and are applicable to withholding of medically indicated treatment from disabled infants. The 'reporting' provisions require only that states must provide by statute that specified persons must report cases of child abuse and neglect to the child protective agency, and that any other person is permitted to report. The provision for "prompt investigation" may include reporting hotlines, field investigations and interviews, home visits, and medical, psychological and social assessments. HHS surveys the various state requirements for reporting and investigating in the Child Abuse Proposed Rules, supra note 20, 49 FED. REg. at 48,161-63.

112 Child Abuse Rules, supra note 7 (to be codified at 45 C.F.R. $\$ 1340.15$ (c)(4)).

${ }^{113}$ See supra notes 78-99 and accompanying text. 
Section 504-based rules in that they are implemented and enforced by state, rather than federal, intervention.

\section{Definition of "Withholding Medically Indicated Treatment"}

"Medical neglect" means the failure to provide adequate medical care. ${ }^{114}$ This includes, but is not limited to, the withholding of medically indicated treatment from a disabled infant with a life-threatening condition. ${ }^{115}$ Section $3^{116}$ defines the term "withholding of medically indicated treatment" as "the failure to respond to the infant's ${ }^{117}$ life threatening conditions $^{118}$ by providing treatment ${ }^{119}$ (including appropriate nutrition,

114 The concept of "medical neglect" should be understood within the wider context of the definition of "child abuse and neglect" in section 3 of the Child Abuse Prevention and Treatment Act of 1974, 42 U.S.C. $\$ 5102$, and in the Child Abuse Rules, supra note 7 (to be codified at 45 C.F.R. $\$ 1340.2$ (d)): "The physical or mental injury, sexual abuse, sexual exploitation, negligent treatment, or maltreatment of a child by a person responsible for the child's welfare under circumstances indicating harm or threatened harm to the child's health or welfare ...."

115 Child Abuse Rules, supra note 7 (to be codified at 45 C.F.R. $\$ 1340.15$ (b)(1)).

${ }^{116}$ Child Abuse Prevention and Treatment Act of 1974, 42 U.S.C. $\$$ 5102, as amended by the Child Abuse Amendments of 1984, \& 121, supra note 7.

117 The term "infant" means: "an infant less than one year of age." The reference to less than one year of age should not be construed to imply that treatment should be changed or discontinued when an infant reaches one year of age, or to affect or limit any existing protections against medical neglect under state law. Thus, the principal focus of the new Child Abuse provisions are for infants under one year old. In such cases the precisely defined standards in the 1984 Amendment and accompanying regulations must be used. For infants over this age, the more general standard of "medical neglect" is to be used. But the more precise standards should be consulted thoroughly in the evaluation of any issue of medical neglect involving an infant over the age of one year who has been continuously hospitalized since birth, who was born prematurely or who has a long term disability. Congressional intent is to recognize that these categories of infant share important characteristics with infants under one year of age. The Child Abuse Rules supra note 7 (to be codified at 45 C.F.R. $\S 1340.15$ (b)(3)(i)); Legislative History, supra note 9, 4 U.S. Code Cong. \& AD. News at 2970. Note that the Child Abuse Proposed Rules stated that the term "infant" always included these three categories of infants over one year of age. The change reflects the intent of the Joint Sponsors that such infants "may" be included. HHS believes that a thorough consideration of the more precise standards should permit an informed judgment on whether they are the most appropriate bases for evaluation of the medical neglect issue. Chile Abuse Rules, supra note 7, 50 FED. REG. at 14,882 . It remains unclear, however, in what circumstances the more precise standards apply to infants who fall within one of the three categories. A "thorough evaluation" of the standards doesn't give any comprehensive indication of whether those standards are to apply in the case in question. Finally, HHS resisted calls for specific inclusion of infants born alive after attempted abortion; but it made clear that infancy begins at the point of live births, regardless of the circumstances of the live birth.

${ }^{118}$ HHS interprets "life threatening condition" to include a condition that, in the treating physician's reasonable medical judgment significantly increases the risk of the onset of complications that may threaten the life of the infant. Thus the Child Abuse provisions would apply in cases where the condition itself was not life threatening (e.g. the risk of serious infection in an open myelomeningocele which is not operated upon). Child Abuse Rules, supra note 7 (to be codified at 45 C.F.R. $\S 1340$, Appendix, ๆ 2).

${ }^{119}$ HHS interprets the term "treatment" in two contexts: (i) in the context of adequate 
hydration, and medication) which, in the physician's reasonable medical judgment ${ }^{120}$ will be most likely to be effective in ameliorating or correcting all such conditions ...." Under the Act, all instances of withholding of appropriate nutrition, hydration or medication from disabled infants with life threatening conditions are forms of medical neglect, irrespective of the circumstances. ${ }^{121}$

The Act does not consider the withholding of medically indicated treatment to be "medical neglect" under the following circumstances:

(a) When the infant is chronically and irreversibly comatose;

(b) When the treatment would-

(i) merely prolong dying; ${ }^{122}$

(ii) not be effective in ameliorating or correcting all of the infant's life-threatening condition; ${ }^{123}$ or

evaluation - "treatment" includes (but is not limited to) "any further evaluation at a facility with specialized capabilities regarding the condition(s) involved that, in the treating physician's reasonable medical judgment, is needed to assure that decisions regarding medical intervention are based on adequate knowledge about the case and the treatment possibilities with respect to the medical conditions involved." This reflects HHS' interpretation that failure to respond to an infant's life threatening conditions by obtaining further or more specialized evaluation which in the physician's opinion is needed could amount to medical neglect. (ii) In the context of multiple treatments-"treatment includes (but is not limited to) multiple medical treatments and/or surgical procedures over a period of time that are designed to ameliorate or correct a life threatening condition or conditions." In evaluating whether treatment is "effective," "futile" or "inhumane," the benefits and adverse effects not merely of one medical procedure, but of an entire plan of treatment, should be considered. Child Abuse Rules, supra note 7 (to be codified at 45 C.F.R. § 1340, Appendix, $\mid \uparrow 3-4$ ).

120 The term "reasonable medical judgment" means one "made by a reasonably prudent physician, knowledgeable about the case and the treatment possibilities with respect to the medical conditions involved." Child Abuse Rules, supra note 7 (to be codified at 45 C.F.R. $\S 1340.15$ (b)(3)(ii)).

121 Child Abuse Rules, supra note 7 (to be codified at 45 C.F.R. $\$ 1340$, Appendix, \$1).

${ }^{122}$ HHS interprets the term "merely prolong dying" as "referring to situations where the prognosis is for death and, in the treating physician's reasonable medical judgment, further or alternative treatment would not alter the prognosis in an extension of time that would render the treatment futile." Child Abuse Rules, supra note 7 (to be codified at 45 C.F.R. $\S 1340$, Appendix, 15). The phrase "death is imminent and treatment will do no more than postpone the act of dying" in the Child Abuse Proposed Rules, supra note 20, is deleted in the final rules.

${ }^{123}$ The term "not to be effective in ameliorating or correcting all the infant's life-threatening conditions" means that, if the disabled infant suffers from more than one life-threatening condition and, in the physician's reasonable medical judgment, there is no effective treatment for one of those conditions, then the infant is not covered by the Amendment except with respect to nutrition, hydration and medication. Legislative History, supra note 9, 4 U.S. CoDE Conc. \& AD. News at 2970. HHS' interpretation is that the term "not be effective in ameliorating or correcting all the infant's life-threatening conditions" does not permit the withholding of treatment in the following two circumstances: (i) in the context of a future life-threatening condition-where one or more of the infant's life-threatening conditions, although not life threatening in the near future, will become so in the more distant future. An example given in the Proposed Rules, supra note 20, 49 FeD. REG. at 48,164, was an infant with a duodenal atresia (a lack of opening in the duodenum) and a second condition such as Down's Syndrome or Tay Sach's disease, in which case surgery to unblock the duodenum should be 
(iii) otherwise be futile in terms of survival of the infant; ${ }^{124}$

(c) The treatment would be virtually futile ${ }^{125}$ in terms of the survival of the infant and the treatment itself under the circumstances would be inhumane. ${ }^{126}$

The selective non-treatment decision, in the above circumstances, must be made in the exercise of the physician's reasonable medical judgment.

\section{Additional State Grants and Assistance for Training, Technical} Assistance and Clearinghouse Activities

Section $4(c)(1)^{127}$ authorizes, but does not mandate, the Secretary to make additional grants to states to develop, establish, operate, or implement procedures or programs for responding to medical neglect under Section $4(b)(2)(k) .{ }^{128}$ The grants would also provide information, education, and training programs for professionals, paraprofessionals, and parents of disabled infants with life threatening conditions. Other grants would be available to set up programs to help obtain or coordinate necessary services, e.g., assisting family access to existing social and health services and financial assistance. Finally, grant funds may facilitate adoptive placement of unwanted infants.

performed. (ii) In the context of palliative treatment-where ameliorative treatment, in the treating physician's reasonable medical judgment, will make a condition more tolerable, such as relieving severe pain, even if the overall prognosis is that the infant will not survive. Thus, if the infant has one life-threatening condition that will cause death in the near future, humane treatment, for example, to relieve severe pain, should be administered. Child Abuse Rules, supra note 7 (to be codified at 45 C.F.R. $§ 1340$, Appendix, $16-7$ ).

124 The term "otherwise futile in terms of survival of the infant" is not discussed in the interpretive guidelines. Its clear meaning is that, even with the treatment, the infant would die. But the issue is when the infant is expected to die. See infra text accompanying notes 150-61. To examine whether treatment is "futile" an entire plan of treatment should be considered. See supra note 119.

${ }^{125}$ HHS's interpretation of the term "virtually futile" is that treatment is highly unlikely to prevent death in the near future." Child Abuse Rules, supra note 7 (to be codified at 45 C.F.R. $\S 1340$, Appendix, ๆ 8).

${ }^{126}$ HHS's interpretation of the term "the treatment itself under such circumstances would be inhumane" is that the "treatment itself involves significant medical contraindications and/or significant pain and suffering for an infant highly unlikely to survive." Child Abuse Rules, supra note 7 (to be codified at 45 C.F.R. \$ 1340, Appendix, I 8). The use of the term "inhumane" in the Act "is not intended to suggest that consideration of the humaneness of a particular treatment is not legitimate in any other context; rather it is recognized that it is appropriate for a physician, in the course of reasonable medical judgment, to consider that factor in selecting among effective treatments." Legislative History, supra note 9, U.S. CodE Cong. \& Ad. News at 2970.

127 The Child Abuse Prevention and Treatment Act of 1974, 42 U.S.C. $\$ 5103$ (1984 \& Supp. 1985), as amended by $\S 123$ of the Child Abuse Amendments of 1984, supra note 7.

${ }^{128}$ For the provisions of $\S 4(b)(2)(k)$ of the Child Abuse Prevention and Treatment Act, see supra notes 107-113 and accompanying text. Section $4(\mathrm{c})(2)$ of the Act mandates the Secretary to provide, either directly or through grants or contracts with public or non-profit organizations, for training and technical assistance programs to assist States with meeting the program and procedure requirements of $\S 4(b)(2)(k)$. 
Section $4(c)(2)^{129}$ requires the Secretary to provide, either directly, or through grants or contracts with public or private non-profit organizations, internal and regional clearinghouses providing current and complete information regarding medical treatment and community services for disabled infants with life-threatening conditions. The clearinghouses will compile, maintain, and disseminate regional directories of community services, as well as the names and telephone numbers of state and local medical organizations. They will also assist in coordinating the availability of appropriate regional education resources for health care personnel. The primary purpose of these clearinghouse efforts is to assist physicians, other professionals, and parents in providing treatment and services for these infants.

The foregoing additional grants focus principally upon the time period when treatment decisions have to be made. The Child Abuse Amendment allocates funds for reporting procedures, teaching, and providing information for health care professionals and parents, but does not materially expand the health, social and habilitation services now available to improve the quality of the handicapped person's life.

\section{Model Guidelines to Establish "Infant Care Review Committees"}

\section{a. Form and Function of the ICRC}

The Secretary has published interim and final Model Guidelines to encourage the establishment of Infant Care Review Committees (ICRCs) within health care facilities. ${ }^{130}$ The ICRSs would educate hospital personnel and families of disabled infants with life threatening conditions, recommend institutional policies and guidelines concerning the withholding of medically indicated treatment from such infants, and review cases involving disabled infants with life-threatening conditions. The model guidelines encourage the establishment of ICRCs in hospitals that provide health care to infants, particularly those hospitals with tertiary-level neonatal care units. The Model. Guidelines contain detailed provisions relating to the membership, ${ }^{131}$ administration $^{132}$ and educational activities ${ }^{133}$ of ICRCs.

129 The Child Abuse Prevention and Treatment Act of 1974, 42 U.S.C. $\$ 5102$ (1984), as amended by $\S 123$ of the Child Abuse Amendments of 1984, supra note 7 . Not more than $\$ 1$ million of the funds appropriated for any fiscal year under $\S 5$ may be used to carry out $\S 4$ (c)(2). For a further discussion of clearinghouse activities, see Child Abuse Rules, supra note 7, 50 FED. REG. 14,884

${ }^{130}$ Interim Model Guidelines for Health Care Providers to Establish Infant Care Review Committee; Notice, 49 FED. REg. 48,170 (1984); Model Guidelines for Health Care Providers to Establish Infant Care Review Committee, Notice, 50 FED. REg. 14,893 (1985) [hereinafter cited as Model Guidelines].

131 The Model guidelines recommend a core multi-disciplinary membership including a physician, a nurse, administrator, social worker, representative of a disability group, lay 
ICRCs are meant to "prevent the withholding of medically indicated treatment from disabled infants with life threatening conditions." ${ }^{134}$ Under the model guidelines, the ICRC should recommend specific policies and guidelines for the hospital which cover the management of specific types of cases and internal review procedures to be followed when such cases occur. The ICRC may require attending physicians to notify it of the presence of an infant with such a specified diagnosis. The ICRC should review existing hospital procedures or recommend new procedures to facilitate effective cooperation and coordination between the hospital and state child protective services. Under the Model Guidelines, the ICRC should review all records involving selective non-treatment decisions to infants. Any deviations from institutional policies should be reviewed and reported.

\section{b. Prospective Review and Counsel in Specified Cases}

The model guidelines further suggest that the hospital, to the extent possible, require in each case that life sustaining treatment continue until the ICRC can review the case and provide advice. In certain circumstances, emergency meetings should be convened within 24 hours or less. ${ }^{135}$ The ICRC should designate one of its members as a "special advocate" for the infant. This person should ensure that all factors favoring the provision of treatment are fully considered.

In cases where disagreement exists between the physician and the infant's family, the Model Guidelines offer certain substantive recommendations:

member and a member of the facility's medical staff to serve as chairperson; the core membership could be supplemented with, for example, a lawyer or a representative of the clergy.

${ }_{132}$ The Model Guidelines recommend that hospitals should provide the ICRC with staff support including legal counsel; the ICRC should recommend procedures to ensure that hospital personnel and patient families are informed of its functions and 24 hour availability; the ICRC should inform itself of all pertinent legal requirements and procedures in state law regarding medical neglect; and the ICRC should maintain confidential records of its deliberations and summaries of specific cases.

${ }^{133}$ The Model Guidelines recommend that ICRCs should provide full and current information to hospital personnel and families concerning medical treatment and resources including information about clearinghouses, community and rehabilitation services and counselling, supportive services, and adoption placement counselling.

${ }^{134}$ The definitions in the Child Abuse Act and Rules are applicable to the Model Guidelines, and constitute the substance of the basic policy of ICRCs. HHS also recommends careful review of its "interpretive guidelines." See supra notes 114-126 and accompanying text.

135 That is, when there is a disagreement between the infant's family and physician or between members of the hospital's medical and/or nursing staff; when a preliminary decision to withhold treatment is made in certain categories of cases pre-determined by the ICRC: or when an emergency meeting is requested by a member of the ICRC, hospital staff or parent of the infant. The confidentiality of persons making a request should be preserved. Emergency meetings should be open to affected parties and their interests must be fully considered. 
(1) The ICRC should counsel that the family's wishes to continue treatment should be respected unless the treatment is medically contra-indicated;

(2) If the family refuses consent to treatment and the ICRC agrees, the ICRC should counsel that treatment be withheld;

(3) If the ICRC disagrees with the family's refusal of consent, then it should counsel that the matter be immediately referred to an appropriate court or child protective services agency, and every effort should be made to continue treatment. This procedure should also be used where the family and physician agree that life sustaining treatment should be withdrawn, but the ICRC disagrees. ${ }^{136}$

The President's Commission for the Study of Ethical Problems in Medicine and Biomedical and Behavioral Research in 1983 provided the thrust for the ICRC proposal. ${ }^{137}$ Since that time, a broad range of medical and health associations have endorsed the concept. ${ }^{138}$ Some courts have been favorably disposed towards consultation with hospital review committees, ${ }^{139}$ while others have been more cautious. ${ }^{140}$ Hospital review committees in the infant care field, or in any other medical ethics context, have not yet been mandated by the courts or statute. ${ }^{141}$

There is no consensus on how such committees should operate and, particularly, whether they should be prescriptive or decision-making in character. The presence of a "special advocate" for the infant, prescriptive routes to be followed when there are disagreements, and retrospective review as a "fault finding" exercise support the criticism that the HHS

${ }^{138}$ See Model Guidelines, supra note 130, 50 FED. REG. at 14,895-96.

${ }^{137}$ President's Commission for the Study of Ethical Problems in Medicine and Biomedical and Behavioral Research, Deciding to Forgo Life-Sustaining Treatment (1983).

${ }^{138}$ Model Guidelines, supra note 130, 50 FEd. REg. at 14,893; See, e.g., American Hospital Association, Guidelines: Hospital Committees on Biomedical Ethics (1984); American Hospital Association, Office of Legal and Regulatory Affairs, Legal Issues and Guidance for Hospital Biomedical Ethics Committees: Report of the Adjunct Legal TASK Force in Biomedical Ethics (1985) [hereinafter cited as Biomedical ETHics].

${ }^{139}$ In re Torres, 357 N.W.2d 2332, 2335-36 (Sup. Ct. Minn. 1984); In re L.H.R., slip op. No. 41,065 (Ga. Sup. Ct. Oct. 16, 1984).

${ }^{140}$ Superintendent of Belchertown State School v. Saikewicz, 373 Mass. 728, 370 N.E.2d 417,434 (1977) ("We take a dim view of any attempt to shift the ultimate decision-making responsibility away from the duly established courts of proper jurisdiction to any committee, panel or group, ad hoc or permanent.").

141 But the court in In re Quinlan, 70 N.J. 10, 355 A.2d 647, cert. denied 429 U.S. 922 (1976), held that an "ethics committee" comprised of physicians to confirm the medical prognosis was mandated. Accord In re Hamlin, 102 Wash.2d 810, 689 P.2d 1372, 1378 (1984). This is different from a multidisciplinary committee which examines more diverse medical/ legal/ethical issues. 
Model Guidelines view ICRCs as quasi-judicial, adversarial bodies. ${ }^{142}$ Yet the regulations can be defended on the ground that a wide ranging membership with some advocacy role may ensure that full and accurate information is available for decision-making. Moreover, multi-disciplinary decision-making also shows a recognition that the issues require social and ethical, as well as medical, expertise for their resolution. Where a life is at stake, it is reasonable to require that treatment continue until a full review is completed.

In evaluating the Model Guidelines it is important to recognize that they operate within the restrictive context of the Child Abuse Amendments of 1984. The basic policy in the Model Guidelines of ensuring that medically indicated treatment is given in all cases appears to taint the ICRC with an air of pre-judgment of cases and issues. Yet such a policy is consistent with the statutory purpose. The prescriptive framework for analyzing such complex and delicate cases flows from the Act and regulations, not from the Model Guidelines.

\section{ANALYSIS OF LEGISLATIVE AND REGULATORY STANDARDS}

\section{A. Child Abuse Standards Measured Against Proposed Standards}

The standard proposed earlier in this essay differs significantly from the Child Abuse Rules. The Child Abuse provisions essentially adopt a vitalist position ${ }^{143}$ whereby, with the exception of three highly restrictive situations, ${ }^{144}$ any treatment which can ameliorate or correct a life threatening condition must be administered. As the Senate report on the Child Abuse Amendments stated:

Under the fundamental tenets of our society, the life of an ablebodied or disabled human being should not be brought to a premature end by parental; physician, or hospital committee decree. ${ }^{145}$

\footnotetext{
142 The Model Guidelines did not deal with a number of difficult questions which must be faced by any institutional review committee-e.g., the problems of keeping committee records and of committee access to patient records including record confidentiality, length and method of retention of records, parent's access to infant's records; problems of "extended" confidentiality to include all members of the committee in abiding by hospital rules and state law; inserting an ethics committee recommendation in the patient's record; discoverability of committee minutes and whether they should be open to the public or held in confidence; immunity from liability of members of the committee; boundaries of the subject matter jurisdiction of the committee; and the role of the attorney who may have a conflict of interest if he also represents the hospital. See generally Bromedical Eтнics, supra note 138.

${ }^{143}$ See supra notes $16-22$ and accompanying text.

${ }^{144}$ See supra notes 122-126 and accompanying text.

${ }^{145}$ Legislative History, supra note 9, 4 U.S. Cone Cong. \& AD. News at 2928.
} 
Such robust vitalism fails to account for people whose disabilities are so grave, functioning so limited, and pain and suffering so unendurable that life is not worth aggressively defending. Society increasingly realizes that the range of justifiable and rational choices can include a decision not to endure life in its hopeless and terminal stages. Courts have followed suit by defending the individual's right to refuse intrusive treatment. As discussed in the section analysing case law, ${ }^{146}$ this right to refuse treatment, based upon clear and narrow "quality of life" 147 criteria, has been extended to incompetent adults; it would be iniquitous to deny infants this right to privacy.

The discussion below juxtaposes the treatment standards proposed by this paper against those set forth in the Child Abuse Amendments of 1984.

\section{1. "The Infant is Chronically and Irreversibly Comatose"}

The Child Abuse statute and regulations require treatment in virtually all cases where the infant has the potential to survive. The only concession the Act makes to a "quality of life" standard is its recognition that treatment can be withheld from an infant who is permanently comatose. The provisions require efficacious medical treatment for any infant with the potential to survive as a conscious being. The provisions disregard any deficit, however large, in conscious functioning, even if the infant has little or no potential for human behavior and social interaction.

The standard proposed in this essay-"the potential of the infant for dealing with, and responding to, sensory information, and experiencing thought is de minimis"148 — provides a broader scope for non-treatment decisions where no humane purpose would be achieved by treating the infant. This standard would apply, for example, in cases of progressive degenerative diseases of the brain or severe chromosome disorders. ${ }^{149}$ Children suffering from such afflictions will barely subsist in their cots and possess only the most basic form of consciousness or perception. It is difficult to differentiate such cases from those of comatose patients except that rudimentary consciousness may be accompanied by the potential for pain and suffering, all the more reason for not fruitlessly sustaining biological life.

\section{Treatment Will "Merely Prolong Dying"}

A major question raised by the Child Abuse provisions concerns the circumstances in which treatment may be withheld from a person who is

\footnotetext{
${ }^{146}$ See supra notes 59,77 and accompanying text.

147 See supra notes 24-25 and accompanying text.

${ }^{148}$ See supra notes $33-38$ and accompanying text.

${ }^{149}$ Id.
} 
terminally ill. The phrase "merely prolong dying"150 suggests a prognosis that the infant will die. However, the provisions do not specify how short a lifespan will justify a non-treatment decision. The proposed rules confined the term "to situations where death is imminent and treatment will do no more than postpone the act of dying." ${ }^{151}$ Medical organizations and the principal sponsors of the Child Abuse Amendments opposed this restrictive definition on the ground that it did not abide by the substantial compromise reached in the development of the bill. ${ }^{152}$

The final rules do not define "merely prolong dying," but instead offer an interpretive, non-binding guideline. While the word "imminent" is not used in the final rules, HHS has not altered its view that "merely prolong dying" is inapplicable when the prognosis of death is in the "more distant," as distinct from "near" future and will give the infant "many years of life." 153

This wording still leaves open the construction of the statutory term. Omission of the word in the Joint Explanatory Statement confirms the intentional decision of the joint sponsors not to introduce the word "imminent." However, the Senate Committee on Labor and Human Resources distinguishes between "infants facing imminent and unavoidable death and other infants whose chances of survival could be improved with medical treatment."154 The Committee cited with approval the Surgeon General, C. Everett Koop, on the question of treatment and prolonging dying: "Some handicapped infants, unfortunately, face imminent death. For such infants it is very important to note that we do not seek to fruitlessly prolong the process of dying ...."155

In discussing a number of cases where treatment had been withheld from infants, the Committee appeared to condone decisions "made in consideration of imminent and unavoidable death," but not those based upon "the child's disabling condition." ${ }^{56}$ There was no express indication

${ }^{130}$ See supra note 122 and accompanying text. The phrase is gramatically awkward for it suggests an extension in duration of dying. More accurately, it would read "prolong the process of dying."

${ }^{151}$ Child Abuse Proposed Rules, supra note 20, at 48,164, 48,167.

152 The letter from the six principal sponsers cited in the Child Abuse Rules, supra note 7 , at 14,879 stated:

In the negotiations leading to the final language, there was much discussion about whether or not to include the word 'imminent' in the statutory definition. It became apparent that 'imminent' would create undue confusion both because it was ambiguous and because the expected time of death cannot be predicted with precision. A decision was made, therefore not to include 'imminent', and we urge that it be dropped in the regulation as well.

${ }^{153}$ Child Abuse Rules, supra note 7, at 14,890-91.

154 Legislative History, supra note 9, 4 U.S. CODE CoNG. \& AD. NEws at 2925.

${ }^{155}$ Legislative History, supra note 9, 4 U.S. Code Cong. \& AD. News at 2926.

${ }^{156}$ Legislative History, supra note 9, 4 U.S. Code Cong. \& AD. News at 2924. 
in the legislative history or the Joint Explanatory Statement that the term "merely prolong dying" specifically referred to imminent death. It does appear, however, that Congress intended that death be impending before efficacious treatment could be withheld. ${ }^{157}$ There is general accord that Congress recognized that "a few children with intensive care might live for months, and occasionally, for years." 158

As suggested earlier in this essay, broader considerations for nontreatment decisions should be applied where the infant has a severely limited life expectancy, together with a cluster of grave, irremediable symptoms. ${ }^{159}$ For example, compare the approach taken under the Child Abuse provisions with the standards proposed in this essay in the case of an infant with Tay Sachs disease. HHS specifically used this example in the proposed rules as a case of a terminally ill infant who should nevertheless be aggressively medically treated. ${ }^{160}$ Most Tay Sachs infants will live less than two years, and rarely to three or four. The overall clinical picture is characterized by profound psychomotor retardation and relentless deterioration, with the child apathetic and unresponsive to exogenous stimuli. Tay Sachs infants rarely sit or crawl. As the disease progresses, the child suffers from blindness and seizures and eventually reaches a vegetative state. ${ }^{161}$ Given the certainty of the prognosis, the extent and gravity of the suffering, and the absence of interactive human experiences, it is reasonable to allow the parent, with professional advice, to make a proxy judgment that treatment should be withheld. This is especially applicable if it is an intrusive kind of treatment such as major heart surgery. Judicial review of such decisions would be an effective and necessary safeguard for the infant in such cases.

3. "The Treatment Would Be Virtually Futile in Terms of the Survival of the Infant and the Treatment Itself Under the Circumstances Would Be Inhumane"

${ }^{157}$ Legislative History, supra note 9, 4 U.S. Code Cong. \& Ad. News at 2928 ("Where death is imminent and inevitable, and where medical intervention merely forestalls the inevitable, this committee acknowledges that refraining from medical intervention may be an ethically and legally acceptable course.").

${ }^{158}$ Legislative History, supra note 9, 4 U.S. Code Cong. \& AD. News at 2924 (quoting Duff \& Campbell, Moral and Ethical Dilemmas in the Special Care Nursery, 289 NEw ENG. J. MED. 890 (1973)).

${ }^{159}$ See supra text accompanying notes $39-46$.

${ }^{160}$ Child Abuse Proposed Rules, supra note 20, at 48,164. The Department specifically avoided using examples of specific diagnoses to elaborate on meaning in the Final Rules because the addition or subtraction of particular complications would change the clinical picture; the medical illustrations given in this essay should also be read with this understanding.

${ }^{101}$ See supra note 41. Perhaps a clearer illustration is Menkes, or Kinky Hair Syndrome described in supra note 42 . In either case, even when the child reaches coma and, as often occurs, develops pneumonia, he or she would have to be treated with antibiotic medication according to the Child Abuse Rules. See infra notes 163-174 and accompanying text. 
The Child Abuse Rules interpret the phrase "virtually futile in terms of survival" to mean that treatment which is highly unlikely to prevent death in the near future. The treatment is "inhumane" if the pain and suffering or other medical contra-indications related to the treatment itself clearly outweigh the slight potential benefit for an infant highly unlikely to survive. ${ }^{162}$ Thus, pain and suffering caused by the medical condition, as opposed to the treatment itself, could not be taken into account.

Primarily concerned with the prognosis of the infant and the efficacy, intrusiveness, and risks of the treatment, the Child Abuse Rules express a "medical efficacy" approach to the non-treatment decision. ${ }^{163}$ The Rules do not consider any measurement of the pain or inhumanity associated with the medical condition or disability itself.

\section{All Infants Must Receive "Appropriate Nutrition, Hydration or} Medication"

Under the Child Abuse Rules all disabled infants, even if they are in an irreversible coma or imminently dying, must receive appropriate nutrition, hydration and medication. ${ }^{164}$ In his evidence to the Senate Committee on the Child Abuse Bill, the Surgeon General said that nourishment in all cases is the "bottom line." 165 If a hospital denies food or care, "it is child abuse." ${ }^{166}$ Nourishment has an "emotional symbolism"167_feeding is an expression of nurturing and caring, certainly for infants and children." 168 This analysis may be correct in the case of an infant who maintains a sucking reflex and will take nourishment voluntarily. However, those infants who do not take nourishment orally must be fed artificially through nasogastric tubes, gastrostomies, and intravenous infusions-"medical procedures with inherent risks and possible side effects, instituted by failed health care providers to compensate for impaired physical functioning." 169

The court in In re Conroy saw nasogastric and other mechanical feeding as the analytical equivalent to mechanical breathing by respirator; both procedures prolong life artificially when the body is no longer able to perform a vital bodily function on its own. ${ }^{170}$ Courts have not precluded

${ }^{162}$ See supra notes 125-126.

${ }^{163}$ See supra note 19 and accompanying text.

${ }^{164}$ See supra text accompanying note 121.

${ }^{165}$ Legislative History, supra note 9, 4 U.S. Code Cong. \& AD. NEws at 2927.

${ }^{166} I d$.

${ }^{167}$ Barber v. Superior Court, 147 Cal. App.3d 1006, 1016, 195 Cal. Rptr. 484, 490 (1983).

${ }^{168}$ In re Conroy, 98 N.J. 321, 372, 486 A.2d 1209, 1236 (1985).

${ }^{169}$ Id. See also Lo \& Dorntrand, Sounding Board: Guiding the Hand that Feeds: Caring for the Demented Elderly, 311 New Eng. J. Med. 402 (1984); Paris \& Fletcher, Infant Doe Regulations and the Absolute Requirement to Use Nourishment and Fluids for the Dying Infant, 11 L. MED. \& HEALTH CARE 210 (1983); Steinbock, Lynn, Children, and Callahan, Must Patients Always be Given Food and Water?, 13 Hastings Cen. RPt. 17 (Oct. 1983).

${ }^{170}$ In re Conroy, 98 N.J. at 372,486 A.2d at 1236 (1985). 
the finding that artificial sustenance of biological life may, in certain circumstances, be an invasion of a person's constitutional right to privacy. ${ }^{171}$ The decisions have been particularly mindful of the potential for pain and other hazards associated with these procedures.

Even more problematic is the fact that the Child Abuse provisions insist upon the use of appropriate medication in all circumstances. Dr. Little, representing the American Academy of Pediatrics, in testimony before the Committee, said: "Obligations to comfort and respect a dying person remain, and infants whose lives are destined to be brief are owed whatever enhancement and relief from suffering that can be provided, including medication for pain and sedation, as appropriate."172

One contradiction which arises immediately is that sedating an infant can interfere with his or her sucking reflex, making the infant less likely to take nourishment by mouth. ${ }^{173}$ Moreover, not all medication is for sedation or the relief of pain; some combat illness or infection. If an infant is in an irreversible coma and, for example, develops pneumonia, it would serve no human purpose to treat him with medication. Yet the Child Abuse provisions mandate such treatment. The Quinlan court observed that the "state's interest contra weakens and the individual's right to privacy grows as the degree of bodily invasion and the prognosis dims." ${ }^{174}$ While medication is not usually an intrusive treatment, the absence of any prospect for a conscious, sapient existence presents a strong claim effectuating the infant's constitutional right to privacy.

\section{B. Responsibility of the State Which Flows from Legislation that Compels the Treatment of Handicapped Infants}

HHS has determined that the Child Abuse Rules are not likely to result in "an annual effect on the economy of $\$ 100$ million or more" or a "significant economic impact on a substantial number" of health care providers. ${ }^{175}$ The Department reasons that the aggregate costs of the Rules are

171 See Barber v. Superior Court, 1437 Cal. App. 3d 1006, 195 Cal. Rptr. 484 (1983).

172 Legislative History, supra note 9, 4 U.S. Code ConG. \& Ad. News at 2927.

${ }^{173}$ See R. v. Arthur, unpublished transcript from official court reporters Marten, Meredith \& Co., Leicester Crown Court, Nov. 3-5, 1981 (an otherwise healthy Down's Syndrome infant was prescribed a narcotic analgesic, dihydrocodeine (DF118), at a dosage of 5 $\mathrm{mg}$, to be administered not less than every 4 hours "as required." The infant was given water, but no nourishment, and antibiotics were withheld when broncho-pneumonia developed. Dr. Arthur's notes read, "Parents do not wish baby to survive. Nursing care only." The doctor was charged and acquitted of attempted murder after a long string of eminent doctors stated that what was done was in accordance with general physician practices).

${ }^{174}$ In re Quinlan, 70 N.J. 10, 41, 355 A.2d 647, 664 (1976), cert. denied, 429 U.S. 922 (1976).

${ }^{175}$ HHS is required to undertake an "impact analysis" of the Rules as provided in Exec. Order No. 12,291, 3 C.F.R. 127 (1981), and the Regulatory Flexibility Act, 5 U.S.C. $\$ 601-12$ 
only those which it generates; aggressive and costly medical care of infants is already an established and growing feature in the United States health care system, quite apart from the new Child Abuse provisions. ${ }^{176}$ In some unknown but small proportion of cases the Rules would require treatment that otherwise would have been withheld. ${ }^{177}$

The Department's assessment of the Rules' impact on aggregate national medical costs is probably accurate. However, the Rules reinforce and encourage a trend in health care towards expert evaluation, transfer to specialized treatment facilities, and aggressive medical treatment to sustain life on the margins of viability. HHS acknowledges that "prudent persons would take care not to expose themselves to possible governmental or legal challenge and one way to do this is to pursue treatment in cases right on the 'margin." "178 HHS repeatedly argues in the preamble to the Child Abuse Rules that by adopting a constant standard of "reasonable medical judgment," the Rules do not fetter reasonable medical decisions. It should be recognized, however, that reasonable physicians operating within the restrictive framework of the Rules will consult not only medical criteria but also the legal standards imposed. The vitalist tone of the Rules redefines "reasonable medical judgment" to include specialist evaluations and aggressive medical treatment. The fact that other existing rules of law and policy already mitigate toward the practice of defensive medicine does not change the character of these Rules as a contributing force in this direction.

Of greater concern is the emotional, financial, and social impact on parents and families. Some will not be able to meet the costs of inordinately expensive medical care mandated by the Child Abuse provisions because of inadequate private insurance coverage. These families may also be confronted with the inadequacy or unavailability of federal or state support programs. This problem exists independently of the Child Abuse provisions, but that provides no consolation for the tragic personal consequences suffered when the Rules compel medical treatment which cannot be paid. ${ }^{179}$

Neither aggregate national costs nor personal costs to families are as important as the life of the infant. The Federal Government has developed

(1985). In addition to aggregate and personal health care costs, there are the procedural, training, and administrative costs to state agencies and health care facilities discussed in the Child Abuse Rules, supra note 7, at 14,887.

${ }^{176}$ The great majority of cases $(80 \%)$ at a tertiary case center are relatively expensive (costing an average of $\$ 8,000$ ) but most of the rest cost $\$ 20,000$ or more and some involve hundreds of thousands of dollars. The average cost is over $\$ 20,000$. Child Abuse Rules, supra note 7, 50 FED. REG. at 14,886.

${ }^{177}$ Child Abuse Rules, supra note 7, at 14,885-87.

${ }^{178}$ Child Abuse Rules, supra note 7, at 14,886.

179 HHS states frankly: "We do not have statutory authority and decline to require States to assume full financial responsibility in the maintenance and medical costs of all such disabled children." Child Abuse Rules, supra note 7, at 14,884. 
a distinct moral posture devoted to life as an ultimate value, but it has not considered its further moral obligation to provide resources to help ensure some minimally tolerable quality of existence once life sustaining treatment has been mandated. The design of a fiscally conservative but moralist federal government, then, is to mandate highly expensive and elaborate medical treatment to sustain the life of the most severely handicapped and least viable of infants while at the same time demanding that health care facilities cut costs; ${ }^{180}$ it requires life long care of handicapped infants by natural or adoptive parents or in institutions, but limits federal assistance for health and social services for handicapped children and adults. "Vitalism" is based upon the worthy moral premise that life is worth preserving at almost any cost. However, if the government wishes to "thrust life" upon severely handicapped infants, particularly without their parents' agreement, it has a concomitant moral and social responsibility to assist in ensuring that reasonably adequate services are available to maximize the child's developmental potential.

The ultimate human and social objective is to enable natural parents to feel that the birth of a handicapped infant, and the decision to rear the child in the family home, will not result in a never-ending dependency without social help. Financial, emotional, and social support for the family carrying the burden of caring for a handicapped person are vital to the social fabric of any community which values the integration of handicapped people. Feasible legislative programs for families with handicapped children include holidays for the child which would allow the parents a respite from total care; financial support to help overcome the special health and mobility needs of the handicapped person; domiciliary assistance to help meet the additional household needs of the family; and adequate educational or occupational training during the day. Society currently is not organized in a way which encourages local communities to share the burden presented by the high dependency displayed by many severely handicapped children. Good quality residential care for severely handicapped adolescents and adults is a necessary corollary to a societal decision to make paramount the handicapped newborn's right to life. If it is right for the State to intervene to ensure that a handicapped neonate should live, it also ought to ensure that individual parents of such children do not have to rear their children without effective assistance.

\section{CONCLUSION}

The new Child Abuse statute and regulations should not deter the courts from further developing standards which recognize handicapped

${ }^{180}$ See Stone, Sounding Board: Law's Influence on Medicine and Medical Ethics, 312 New ENc. J. MED. 309, 310 (1985) ("Baby Doe" regulations impel the physician to ignore cost and effectiveness considerations, while other recent federal and state regulations have been aimed at creating incentives to lower health care costs). 
infants' constitutional right to privacy. These judicial standards should be congruent with those already being developed for incompetent adults. Since constitutional rights take precedence over statutes and regulations, courts should be prepared to effectuate the infant's right to privacy even where the Child Abuse provisions would require treatment including hydration, nutrition, and medication. The criteria put forward in this essay may provide a useful signpost in developing comprehensive and coherent standards to assess where non-treatment best serves the ward's interests. 